象

$x$
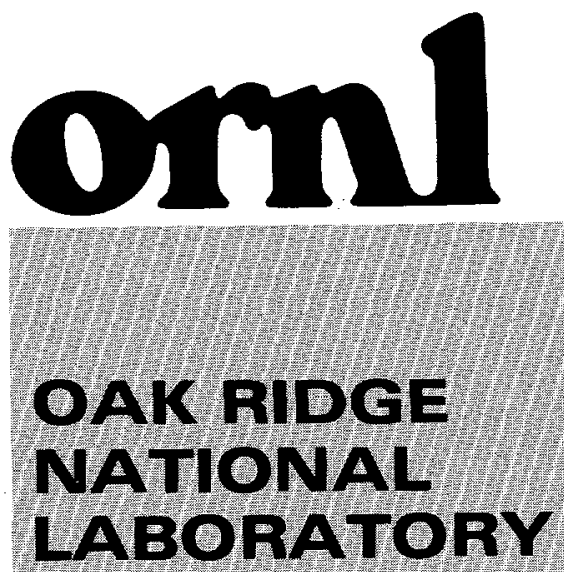

LOCNHFED AARTIF

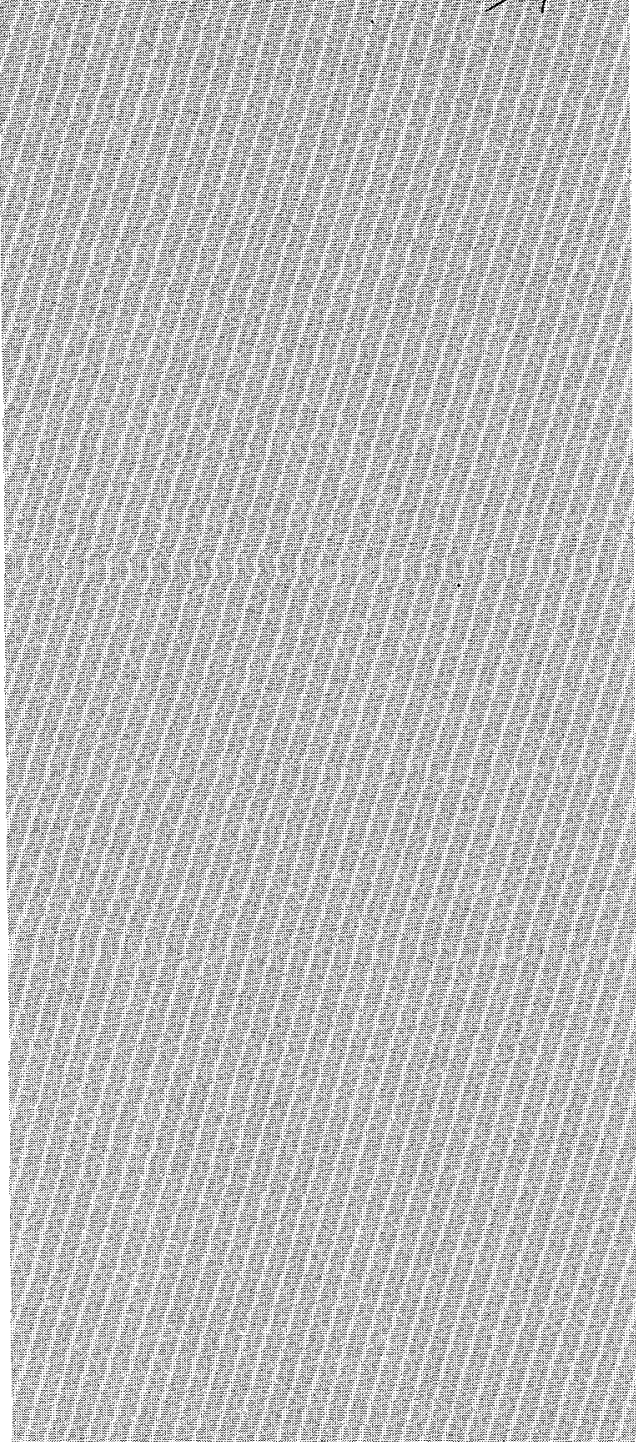

MANAGED AND OPERATED BY LOCKHEED WARTIN ENERGY RESEARCH CORPORATION FOA THE UNTED STATES DEPARTMENT OF ENERGY

\section{Prevention of Solids Formation: Results of the FY 1999 Studies}

\author{
R. D. Hunt \\ E. C. Beahm \\ C. W. Chase \\ J. L. Collins \\ T. A. Dillow \\ C. F. Weber
}

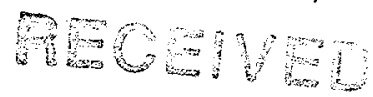

Fon 112 20?

잔. 
This report has been reproduced from the best available copy.

Reports are available to the public from the following source.

National Technical Information Service

5285 Port Royal Road

Springfield, VA 22161

Telephone 703-605-6000 (1-800-553-6847)

TDD 703-487-4639

Fax 703-605-6900

E-mail orders@ ntis.fedworld.gov

Web site www.ntis.gov/ordering.htm

Reports are available to U.S. Department of Energy (DOE) employees, DOE contractors, Energy

Technology Data Exchange (ETDE) representatives, and International Nuclear Information

System (INIS) representatives from the following source.

Office of Scientific and Technical Information

P.O. Box 62

Oak Ridge, TN 37831

Telephone 865-576-8401

Fax 865-576-5728

E-mail reports@adonis.osti.gov

Web site www.osti.gov/products/sources.html

Reports produced after January 1,1996, are generally available via the DOE Information Bridge.

Web site www.doe.gov/bridge

This report was prepared as an account of work sponsored by an agency of the United States government. Neither the United States government nor any agency thereof, nor any of their employees, makes any warranty,

express or implied, or assumes any legal liability or responsibility for the accuracy, completeness, or usefulness of any information, apparatus, product, or process disclosed, or represents that its use would not infringe privately owned rights. Reference herein to any specific commercial product, process, or service by trade name, trademark, manufacturer, or otherwise, does not necessarily constitute or imply its endorsernent, recommendation, or favoring by the United States govemment or any agency thereof. The views and opinions of authors expressed herein do not necessarily state or reflect those of the United States government or any agency thereof. 


\section{DISCLAIMER}

\section{Portions of this document may be illegible in electronic image products. Images are produced from the best available original document.}


Chemical Technology Division

Prevention of Solids Formation: Results of the FY 1999 Studies
R. D. Hunt
E. C. Beahm
C. W. Chase
J. L. Collins
T. A. Dillow
C. F. Weber*

*ORNL, Computational Physics and Engineering Division, Oak Ridge, Tennessee.

Date Published: December 1999

\author{
Prepared by \\ OAK RIDGE NATIONAL LABORATORY \\ Oak Ridge, Tennessee 37831-6285 \\ managed by \\ LOCKHEED MARTIN ENERGY RESEARCH CORP. \\ for the \\ U.S. DEPARTMENT OF ENERGY \\ under contract DE-AC05-96OR22464
}




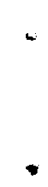




\section{CONTENTS}

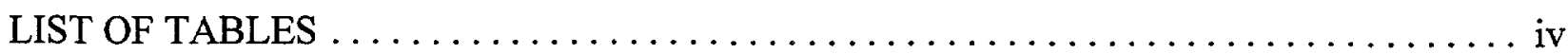

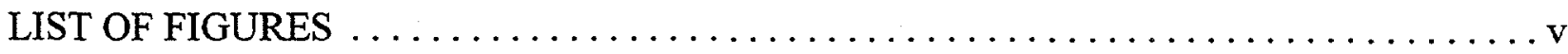

EXECUTIVE SUMMARY $\ldots \ldots \ldots \ldots \ldots \ldots \ldots \ldots \ldots \ldots \ldots \ldots \ldots \ldots \ldots \ldots$ vii

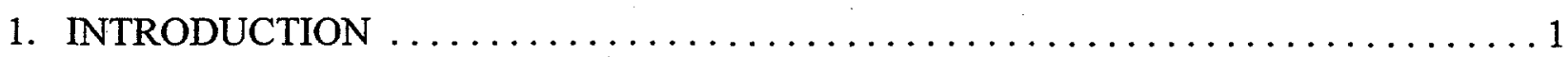

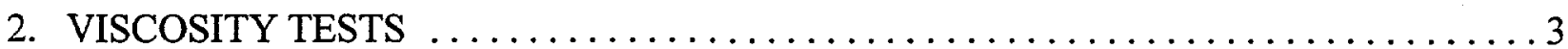

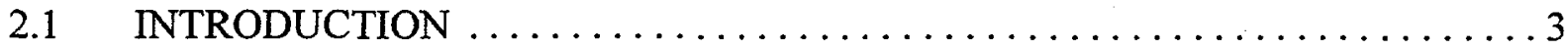

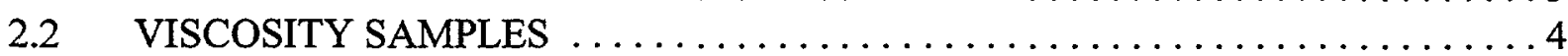

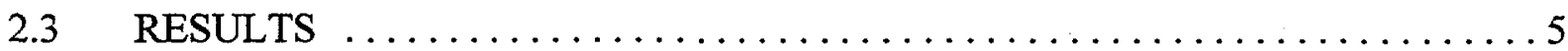

2.3.1 Viscosity During Gradual Waste Cooling $\ldots \ldots \ldots \ldots \ldots \ldots \ldots \ldots$

2.3.2 Viscosity After a Simulated Pump Failure $\ldots \ldots \ldots \ldots \ldots \ldots \ldots \ldots$

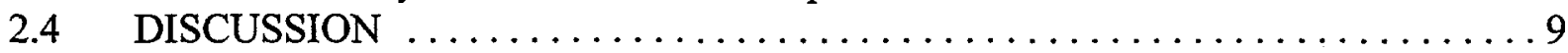

3. WATER WASHES AND CAUSTIC LEACHES OF SLUDGE FROM TANK S-104 _ . 10

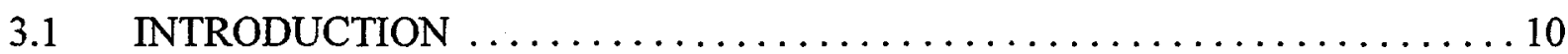

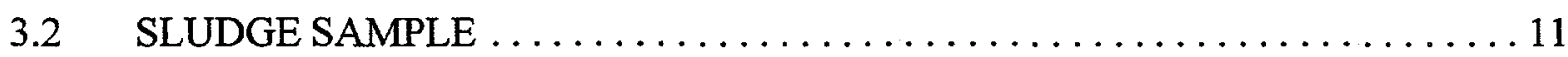

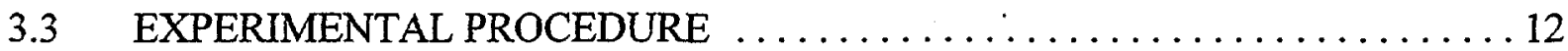

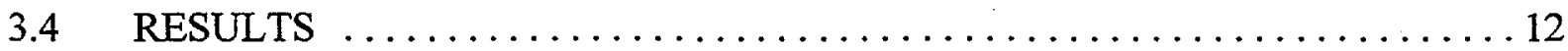

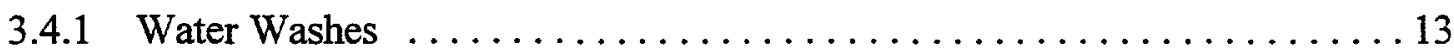

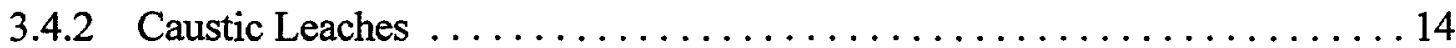

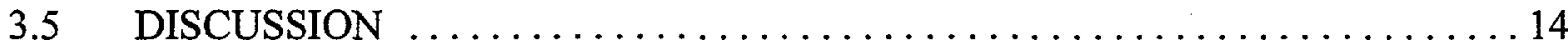

3.5.1 Water Washes ..................................... 14

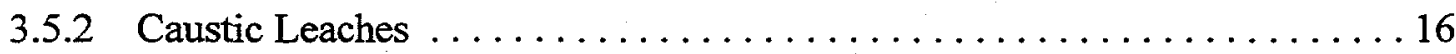

4. CHEMICAL SIMULANT OF THE SODIUM PHOSPHATE PLUG $\ldots \ldots \ldots \ldots \ldots$

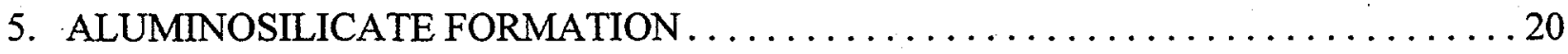

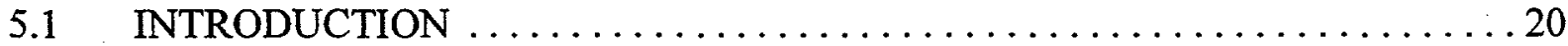

5.2 MODELING ALUMINOSILICATE FORMATION . . . . . . . . . . . 21

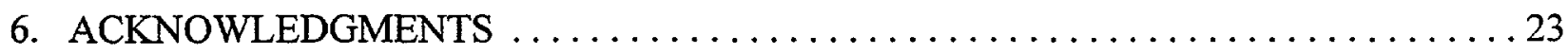

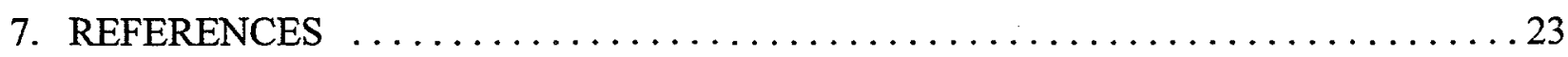

APPENDIX A. MODEL FOR THE SOLUBILITIES OF SILICATE SPECIES . . . . . . A-1 


\section{LIST OF TABLES}

Table

$\underline{\text { Page }}$

1 Highest and lowest concentrations of the key components in the Hanford tanks .....4

2 High and low concentrations of the key components in the exploratory tests ........ 4

3 Concentrations of the key components in the viscosity samples $\ldots \ldots \ldots \ldots \ldots \ldots$

4 Viscosity of the Hanford waste components during gradual cooling $\ldots \ldots \ldots \ldots 6$

5 Volume of the gravity-settled solids in the viscosity samples for Hanford . . . . . . . . 6

6 Types of solids in the viscosity samples after the gradual waste cooling $\ldots \ldots \ldots \ldots 7$

7 Simulated pump failure: viscosity and volume of gravity-settled solids $\ldots \ldots \ldots \ldots 8$

8 Hanford Tank S-104: sludge mass and amounts of key constituents ........... 12

9 Inhibited water washes of sludge from Hanford Tank $S-104 \ldots \ldots \ldots \ldots \ldots \ldots$

10 Leach conditions and mass changes for the washed sludge solids from Tank S-104 . . 15

11 FY 1997 and FY 1999 leach conditions and results for sludge from Tank S-104 . . . . 18

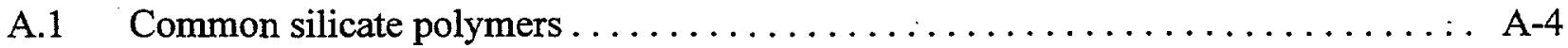

A.2 Experimental values on the solubilities of silicates $\ldots \ldots \ldots \ldots \ldots \ldots \ldots \ldots$ A-5

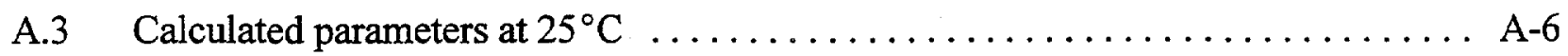

A.4 Optimal formation constants $\ldots \ldots \ldots \ldots \ldots \ldots \ldots \ldots \ldots \ldots \ldots \ldots \ldots \ldots \ldots \ldots \ldots \ldots \ldots$ A-7 


\section{LIST OF FIGURES}

Figure $\quad \underline{\text { Page }}$

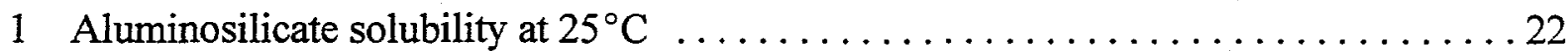

A.1 $\mathrm{pH}$ of NMR solutions $\ldots \ldots \ldots \ldots \ldots \ldots \ldots \ldots \ldots \ldots \ldots \ldots \ldots \ldots \ldots \ldots$

A.2 $\mathrm{Q}^{0}$ connectivity group $\ldots \ldots \ldots \ldots \ldots \ldots \ldots \ldots \ldots \ldots \ldots \ldots \ldots \ldots \ldots$

A.3 $\mathrm{Q}^{1}$ connectivity group $\ldots \ldots \ldots \ldots \ldots \ldots \ldots \ldots \ldots \ldots \ldots \ldots \ldots \ldots \ldots$

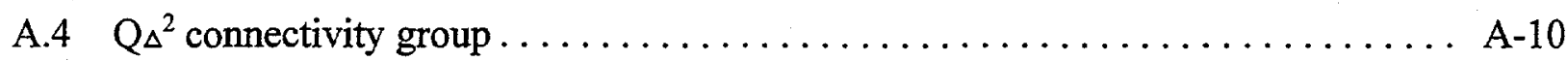

A.5 $\mathrm{Q}^{2}$ connectivity group $\ldots \ldots \ldots \ldots \ldots \ldots \ldots \ldots \ldots \ldots \ldots \ldots \ldots \ldots \ldots \ldots$

A.6 $\mathrm{Q}_{\Delta}^{3}$ connectivity group $\ldots \ldots \ldots \ldots \ldots \ldots \ldots \ldots \ldots \ldots \ldots \ldots \ldots \ldots \ldots$

A.7 $\mathrm{Q}^{3}$ connectivity group $\ldots \ldots \ldots \ldots \ldots \ldots \ldots \ldots \ldots \ldots \ldots \ldots \ldots \ldots \ldots$

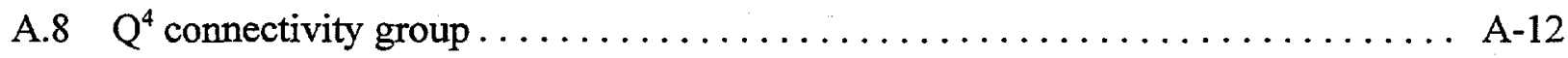

A.9 Solubilities in neutral salt solutions: $\boldsymbol{\nabla}-\mathrm{NaNO}_{3}$ and $\boldsymbol{\Delta}-\mathrm{KNO}_{3} \ldots \ldots \ldots$

A.10 Silicate solubility in sodium hydroxide solutions $\ldots \ldots \ldots \ldots \ldots \ldots \ldots \ldots$ A-13

A.11 Silicate solubility in sodium hydroxide and $1 M$ sodium chloride solutions ...... A-14

A.12 Silicate solubility in sodium hydroxide and $3 M$ sodium chloride solutions ...... A-14 
$\cdot$ 


\section{EXECUTIVE SUMMARY}

Tank farm operations at Hanford and Savannah River have been adversely affected by unintentional solids formations. At Hanford, a new cross-site transfer line had to be built because nearly all the original transfer lines were no longer operational due to plugs. At Savannah River, operations at its evaporator system were suspended while a plug in the gravity drain line was physically removed at considerable expense. The plugs at Hanford and Savannah River, which have been characterized, were primarily due to sodium phosphate and sodium aluminosilicate, respectively. Since most pipeline plugs have not been characterized, this task continues to investigate solids formation in a number of chemical systems that are found in the waste transfers and in proposed remediation processes. In response to the waste transfers at Hanford, viscosity tests were performed to determine the key chemicals that can lead to transfer problems. This initial study indicates that the phosphate concentration, ionic strength, and temperature must be controlled to prevent plugs during waste transfers at Hanford. Further experiments are under way to determine safe transfer conditions based on concentrations, ionic strength, and temperature. In addition, the number of components in the initial tests was limited to avoid an excessive number of experiments. Additional components such as nitrite and carbonate will be added to the test matrix. The results will be used to develop safe operating windows for safe waste transfers at Hanford. In addition to the waste transfer, unwanted solids formation can occur during waste processing activities such as the Enhanced Sludge Washing (ESW). Previous work has shown that phosphate gels and particles are formed as the hot leach solutions from the ESW process are permitted to cool. In another study, insoluble aluminosilicates apparently formed during the hot caustic leaching, which significantly reduced the performance of the ESW process. The aluminosilicates, as well as the phosphate gels from the ESW process, could also form a pipeline plug. This study confirmed the formation of aluminosilicates during the ESW process and demonstrated the importance of a thorough water wash prior to the caustic leaches. The water wash improves the performance and the reproducibility of the ESW process. A key difference in the leach tests with washed sludge and unwashed sludge was the higher ionic strength in the unwashed tests due to the presence of water-soluble salts. In response to the aluminosilicate plug at Savannah River, an equilibrium model on the solubilities of silicate 
species at $25^{\circ} \mathrm{C}$ was developed. After the solubilities of silicon and aluminum species at higher temperatures are incorporated into the model, safe operating windows for the evaporator system will be provided to the tank farm operators. Finally, a simulated chemical plug based on the sodium phosphate plug was developed and provided to the Retrieval Program of the Tanks Focus Area to test recovery methods. Additional simulated plugs have been requested. 


\section{INTRODUCTION}

Solid formations in Hanford and Savannah River tank waste solutions have been observed during routine tank farm operations such as waste transfers and liquid additions. In some cases, the newly generated solids have led to catastrophic results. For example, nearly all the cross-site transfer lines at Hanford are no longer functional due to plugs. Furthermore, most of the waste transfers have led to partial line plugs, and substantial amounts of water were added to the tank system in numerous efforts to remove the plugs. Similarly, the gravity drain line of the 242-16H Evaporator at Savannah River became plugged with cancrinite, which is a nitrated sodium aluminosilicate. Another example of unintentional solids formation involved the Enhanced Sludge Washing (ESW) tests of actual sludge samples (Beahm et al., 1997; Beahm et al., 1998; Hunt et al., 1998; Lumetta et al., 1998). The ESW process has been selected as the baseline treatment technology for Hanford sludges, and its primary objective is to remove aluminum from the sludge prior to vitrification. When aluminum and silicon are in caustic leach solution, they can react to form an aluminosilicate precipitate. In one case (Lumetta et al., 1998), this aluminosilicate precipitate remained insoluble to further caustic leaching, while in another study (Hunt et al., 1998), the precipitate became soluble with increased leaching time. In addition, phosphate gels and particles were observed in several of the hot caustic solutions as they were permitted to cool. Both the aluminosilicate and phosphate gels can lead to plugged pipelines.

Due to the transfer line plugs, the Hanford tank farm has developed waste acceptance criteria that a waste must pass before it can be transferred (Shekarriz et al., 1997). The criteria, which includes physical properties such as viscosity, specific gravity, and percent solids, is based primarily on past operational experience. Unfortunately, the chemistry of the waste solutions was not included in the criteria even though the tank farm operators are fully aware of its importance. The key reasons for the exclusion of chemistry from the acceptance criteria involved the lack of characterization of the waste solutions and the complex chemistry of the waste solutions and solids. In response to the characterization problem, liquid and solid samples from most of the Hanford tanks have been thoroughly characterized. In addition, the Department of Energy (DOE) is also developing monitoring systems, which permit in situ, real-time analysis of the tank waste solutions. Other DOE 
tasks have been studying the chemistry/solubilities of key components such as aluminum, fluorides, phosphates, and silicates. The results of these tasks continued to be incorporated into models such as the Environmental Simulation Program (ESP), which has been used to predict the effects of tank farm operations such as salt cake dissolution.

With improvements in characterization and modeling capabilities, tank farm operators have requested that the chemistry of the waste solution be incorporated into its waste acceptance criteria. The ability to predict solids formation based on the chemistry and physical properties will result in operating windows in which solids formation will not interrupt tank farm activities. The new capabilities are also expected to improve understanding of the sludge dissolution process, which can help to minimize the formation of unwanted solids during and after sludge processing.

This FY 1999 effort focused on several different aspects of solids formation. Viscosity tests were performed to determine the key chemicals that can lead to transfer problems at Hanford. Additional experiments are under way in an effort to determine safe transfer conditions based on waste composition and temperature. Unintentional solids formation can occur during and after the ESW process. The potential of aluminosilicate formation during the ESW process and the need for a thorough water wash prior to the caustic leaches were examined. In addition, the effects of process variables such as sodium hydroxide concentration, temperature, and leaching time on the efficacy of the ESW process with realistic liquid-to-solid ratios were measured. A chemical simulant of the sodium phosphate plug was also developed for use in the Retrieval Program of the Tanks Focus Area. During a university contest, several processes to remove the pipeline plugs were evaluated with the simulated sodium phosphate plug. Additional chemical simulations of actual pipeline plugs will be performed in FY 2000. In response to the plugged gravity drain line at Savannah River, a model demonstrating the solubility of silicate species in caustic at $25^{\circ} \mathrm{C}$ was developed. During FY 2000, this model will be expanded to include higher temperatures. The results and findings for each area of this effort are presented below. 


\section{VISCOSITY TESTS}

\section{$2.1 \quad$ INTRODUCTION}

Reports on previous pipeline plugs at Hanford (Colton et al., 1998) were evaluated. Unfortunately, very few of the pipeline plugs were retrieved and characterized, so only sodium orthophosphate needle-like crystals are known to have plugged a Hanford pipeline (Herting, 1980). While very little quantitative information on the plugs is available, the tank farm operators have obtained a considerable amount of qualitative results such as the maximum safe aluminum concentration (McKay, 1993). When these results were combined with chemical inventories of the Hanford tanks and the observation of natrophosphate during the FY 1997 study on solids formation (Beahm et al., 1997), seven chemical components which could potentially impact the viscosity of Hanford tank wastes were identified. The components are aluminate/alumina, fluoride, hydroxide, nitrate, phosphate, silicon, and sulfate. While sodium and water are also present in each of the samples, they were not explicitly included as variables. Other components such as nitrite, potassium, and carbonate were considered, but they were not included in order to avoid an excessive number of exploratory experiments. In addition, the behavior of nitrite and potassium are comparable with nitrate and sodium, respectively, and their contributions to precipitation or changes in viscosity are primarily through ionic strength. Sulfate and carbonate have the same electrical charge. Therefore, nitrite is considered as part of nitrate, potassium as part of sodium, and carbonate as part of sulfate. In future viscosity tests, changes to the first seven components will be made as necessary.

The literature review and the results from FY 1998 investigation of solids formation (Beahm et al., 1998) were used to develop the first chemical simulant of a Hanford pipeline plug. The chemical simulant of the sodium phosphate plug, which was used in the university contest, consisted of $3 \mathrm{~m}$ sodium hydroxide and/or sodium nitrate, $0.9 \mathrm{~m}$ sodium phosphate, and $0.3 \mathrm{~m}$ sodium fluoride. These concentrations are reasonable based on the chemical inventory in the Hanford tanks. This solution was prepared at $60-80^{\circ} \mathrm{C}$ and permitted to cool to ambient temperature in a pipe. The solutions without the sodium nitrate were used in the contest. 


\subsection{VISCOSITY SAMPLES}

A two-level seven-factor partial factorial was used to design the initial set of viscosity tests which utilized only two concentrations for each component. The chemical inventories of the Hanford tanks were analyzed to determine the highest and lowest concentrations for the seven components. These concentrations, which are displayed in Table 1, were used in the initial set of viscosity samples. Sodium aluminate or aluminum hydroxide, sodium fluoride, sodium hydroxide, sodium nitrate, trisodium phosphate, sodium silicate, sodium sulfate, and deionized water were used to prepare the viscosity samples. However, preparation of the first set of viscosity samples was halted because the solids content of some of the samples was too high for a realistic viscosity evaluation. The highest specific gravity in the initial set of viscosity samples was $1.8 \mathrm{~g} / \mathrm{mL}$, while the specific gravity in actual tank supernatants can be as high as $1.4 \mathrm{~g} / \mathrm{mL}$. Therefore, nearly all the concentrations in the viscosity samples were reduced by a factor of 2 . The high and low concentrations that were used in the preparation of the second set of viscosity samples are shown in Table 2. The compositions of the actual samples are presented in Table 3. The highest specific gravity in the second group of viscosity samples was $1.4 \mathrm{~g} / \mathrm{mL}$.

Table 1. Highest and lowest concentrations of the key components in the Hanford tanks (components measured in moles $/ \mathrm{L}$ )

\begin{tabular}{lccccccc}
\hline & $\mathrm{Al}(\mathrm{OH})_{4}{ }^{-}$ & $\mathrm{F}^{-}$ & $\mathrm{OH}^{-}$ & $\mathrm{NO}_{3}{ }^{-}$ & $\mathrm{PO}_{4}{ }^{3-}$ & $\mathrm{SiO}_{2}$ & $\mathrm{SO}_{4}{ }^{2-}$ \\
\hline Highest & 2.0 & 0.4 & 8.0 & 8.0 & 1.0 & 0.5 & 0.5 \\
Lowest & 0.2 & 0.02 & 1.0 & 1.0 & 0.05 & 0.05 & 0.05 \\
\hline
\end{tabular}

Table 2. High and low concentrations of the key components in the exploratory tests (components measured in moles/L)

\begin{tabular}{cccccccc}
\hline & $\mathrm{Al}(\mathrm{OH})_{4}{ }^{-}$ & $\mathrm{F}^{-}$ & $\mathrm{OH}^{-}$ & $\mathrm{NO}_{3}{ }^{-}$ & $\mathrm{PO}_{4}{ }^{3-}$ & $\mathrm{SiO}_{2}$ & $\mathrm{SO}_{4}{ }^{2-}$ \\
\hline High & 1.0 & 0.2 & 4.0 & 4.0 & 0.5 & 0.25 & 0.25 \\
Low & 0.1 & 0.01 & 1.0 & 1.0 & 0.025 & 0.025 & 0.025 \\
\hline
\end{tabular}


Table 3. Concentrations of the key components in the viscosity samples (components measured in moles/L)

\begin{tabular}{cccccccc}
\hline Sample ID & $\mathrm{Al}(\mathrm{OH})_{4}^{-a}$ & $\mathrm{~F}^{-}$ & $\mathrm{OH}^{-}$ & $\mathrm{NO}_{3}^{-}$ & $\mathrm{PO}_{4}^{3-}$ & $\mathrm{SiO}_{2}$ & $\mathrm{SO}_{4}^{2-}$ \\
\hline $\mathrm{S} 1$ & 0.1 & 0.01 & 1.0 & 1.0 & 0.025 & 0.025 & 0.025 \\
$\mathrm{~S} 2$ & 0.1 & 0.01 & $\mathbf{4 . 0}$ & 1.0 & $\mathbf{0 . 5}$ & $\mathbf{0 . 2 5}$ & $\mathbf{0 . 2 5}$ \\
$\mathrm{S} 3$ & 0.1 & $\mathbf{0 . 2}$ & 1.0 & $\mathbf{4 . 0}$ & 0.025 & $\mathbf{0 . 2 5}$ & $\mathbf{0 . 2 5}$ \\
$\mathrm{S} 4$ & 0.1 & $\mathbf{0 . 2}$ & $\mathbf{4 . 0}$ & $\mathbf{4 . 0}$ & $\mathbf{0 . 5}$ & 0.025 & 0.025 \\
$\mathrm{~S} 5$ & $\mathbf{1 . 0}$ & 0.01 & 1.0 & $\mathbf{4 . 0}$ & $\mathbf{0 . 5}$ & $\mathbf{0 . 2 5}$ & 0.025 \\
$\mathrm{~S} 6$ & $\mathbf{1 . 0}$ & 0.01 & $\mathbf{4 . 0}$ & $\mathbf{4 . 0}$ & 0.025 & 0.025 & $\mathbf{0 . 2 5}$ \\
$\mathrm{S} 7$ & $\mathbf{1 . 0}$ & $\mathbf{0 . 2}$ & 1.0 & 1.0 & $\mathbf{0 . 5}$ & 0.025 & $\mathbf{0 . 2 5}$ \\
$\mathrm{S} 8$ & $\mathbf{1 . 0}$ & $\mathbf{0 . 2}$ & $\mathbf{4 . 0}$ & 1.0 & 0.025 & $\mathbf{0 . 2 5}$ & 0.025 \\
\hline
\end{tabular}

aThe high concentrations are in bold.

\subsection{RESULTS}

\subsubsection{Viscosity During Gradual Waste Cooling}

The $20-\mathrm{mL}$ samples were shaken at $80^{\circ} \mathrm{C}$ for 2 weeks prior to the viscosity measurements. Nearly all the $80^{\circ} \mathrm{C}$ samples contained solids which had settled to the bottom of the centrifuge tube during the agitation. These solids were resuspended into the solution before $16 \mathrm{~mL}$ of the sample was transferred into the preheated small sample adapter for the Brookfield DV-III rheometer. The sample was then permitted to equilibrate for $15 \mathrm{~min}$. For each sample, two viscosity tests were performed in an effort to determine the effects of shear rate and time. During the shear rate tests, the shear rate was varied from $12 \mathrm{~s}^{-1}$ to $122 \mathrm{~s}^{-1}$ to $12 \mathrm{~s}^{-1}$. A particular shear rate was maintained for a period of $2 \mathrm{~min}$ before it was increased or decreased by increments of $12 \mathrm{~s}^{-1}$. In the time tests, a shear rate of $61 \mathrm{~s}^{-1}$ was applied to the sample for $5 \mathrm{~min}$. The viscosity results of the time tests are presented in Table 4. At the end of the $80^{\circ} \mathrm{C}$ tests, the samples were allowed to equilibrate at $70^{\circ} \mathrm{C}$ for 1 week prior to the next set of viscosity measurements. At $70^{\circ} \mathrm{C}$, all the viscosity samples 
contained solids. The 1 -week equilibration period was repeated at 60 and $50^{\circ} \mathrm{C}$. Prior to the $50^{\circ} \mathrm{C}$ viscosity measurements, the volume of the settled solids in each sample was determined, and the results are presented in Table 5. It should be noted that the volume below the spindle in the small sample adapter is $2.6 \mathrm{~mL}$. Since solids settled into this void space during most of the viscosity tests, the viscosity measurements should be considered to be minimum values. After the $50^{\circ} \mathrm{C}$ viscosity tests, the equilibration period for the next lower temperature was reduced to 3.5 days, and the temperature was reduced in increments of $5^{\circ} \mathrm{C}$ until the temperature reached $10^{\circ} \mathrm{C}$.

Table 4. Viscosity of the Hanford waste components during gradual cooling (viscosity measured in $\mathrm{cP}$ )

\begin{tabular}{lcccccccccccc}
\hline ID & $80^{\circ} \mathrm{C}$ & $70^{\circ} \mathrm{C}$ & $60^{\circ} \mathrm{C}$ & $50^{\circ} \mathrm{C}$ & $45^{\circ} \mathrm{C}$ & $40^{\circ} \mathrm{C}$ & $35^{\circ} \mathrm{C}$ & $30^{\circ} \mathrm{C}$ & $25^{\circ} \mathrm{C}$ & $20^{\circ} \mathrm{C}$ & $15^{\circ} \mathrm{C}$ & $10^{\circ} \mathrm{C}$ \\
\hline S1 & $<1$ & $<1$ & $<1$ & $<1$ & 1.0 & 1.0 & 1.1 & 1.1 & 1.2 & 1.4 & 1.6 & 1.8 \\
S2 & 2.0 & 2.3 & 2.4 & 2.4 & 2.7 & 7.2 & 2.0 & $238^{a}$ & 1.8 & 2.0 & 2.3 & 2.6 \\
S3 & 1.1 & 1.1 & 1.2 & 1.4 & 1.6 & 1.7 & 1.8 & 2.0 & 2.0 & 2.2 & 2.5 & 2.8 \\
S4 & 1.8 & 2.0 & 2.2 & 2.4 & 3.0 & 3.0 & 3.3 & 3.6 & 3.6 & 3.6 & 3.7 & 4.7 \\
S5 & 2.0 & 2.2 & 2.2 & 2.2 & 2.2 & 7.3 & 4.3 & $163^{a}$ & 2.0 & 2.2 & 2.5 & 2.8 \\
S6 & 2.3 & 2.5 & 2.7 & 3.3 & 3.7 & 3.9 & 3.9 & 4.1 & 4.1 & 4.5 & 5.4 & 6.6 \\
S7 & 1.1 & 1.2 & 1.2 & 1.3 & 1.5 & 1.5 & 1.6 & 1.6 & 1.7 & 2.0 & 2.2 & 2.5 \\
S8 & 1.3 & 1.5 & 1.7 & 2.0 & 2.2 & 2.3 & 2.4 & 2.4 & 2.4 & 2.8 & 3.3 & 3.9 \\
\hline
\end{tabular}

${ }^{a}$ Shear rate of $1.2 \mathrm{~s}^{-1}$.

Table 5. Volume of the gravity-settled solids in the viscosity samples for Hanford (volume measured in $\mathrm{mL}$ )

\begin{tabular}{cccccccccc}
\hline ID & $50^{\circ} \mathrm{C}$ & $45^{\circ} \mathrm{C}$ & $40^{\circ} \mathrm{C}$ & $35^{\circ} \mathrm{C}$ & $30^{\circ} \mathrm{C}$ & $25^{\circ} \mathrm{C}$ & $20^{\circ} \mathrm{C}$ & $15^{\circ} \mathrm{C}$ & $10^{\circ} \mathrm{C}$ \\
\hline S1 & 0.2 & 0.2 & 0.2 & 0.2 & 0.2 & 0.2 & 0.2 & 0.2 & 0.2 \\
S2 & 1.4 & 1.4 & 3.1 & 1.4 & 1.4 & 5.1 & 4.7 & 3.5 & 3.5 \\
S3 & 0.2 & 0.9 & 0.9 & 0.9 & 0.9 & 0.9 & 0.9 & 0.9 & 0.9 \\
S4 & 0.6 & 2.7 & 2.7 & 2.7 & 2.7 & 2.7 & 2.7 & 2.7 & 2.7 \\
S5 & 1.4 & 1.4 & 2.7 & 0.9 & 0.9 & 0.9 & 3.1 & 3.1 & 3.1 \\
S6 & 0.1 & 0.1 & 0.1 & 0.1 & 0.1 & 0.2 & 0.2 & 0.2 & 0.2 \\
S7 & 2.7 & 2.7 & 2.7 & 2.7 & 2.7 & 1.8 & 1.8 & 2.2 & 2.2 \\
S8 & 0.9 & 0.9 & 1.4 & 1.4 & 1.4 & 1.4 & 1.4 & 1.4 & 1.4 \\
\hline
\end{tabular}


At the conclusion of the viscosity tests, the samples were permitted to equilibrate at room temperature. They were then evaluated for particle type and adhesiveness to other sample particles and to metal. The results of this evaluation are presented in Table 6. Other observations were made during the course of the viscosity measurements. First, the S2 sample with high hydroxide, phosphate, silicon, and hydroxide and the $\mathrm{S} 5$ sample with high aluminum, nitrate, phosphate, and silicon were the first samples to coat the bottom of the small sample adapter during the viscosity measurements. Second, the $\mathrm{S} 2$ and $\mathrm{S} 5$ samples changed from gel $\left(40^{\circ} \mathrm{C}\right)$ to gel with crystals $\left(35^{\circ} \mathrm{C}\right)$ to entirely gel $\left(30^{\circ} \mathrm{C}\right)$ to primarily crystals $\left(25^{\circ} \mathrm{C}\right)$ as the temperature was reduced. Third, a cloud appeared above the settled solids at $20^{\circ} \mathrm{C}$ for the $\mathrm{S} 4$ sample with high fluoride, hydroxide, nitrate, and phosphate. Fourth, a similar cloud appeared with the S2 sample at $15^{\circ} \mathrm{C}$. Fifth, the solids in the S1 sample with low concentrations of all components and in the S6 sample with high aluminum, hydroxide, nitrate, and sulfate remained suspended through all the viscosity tests.

Table 6. Types of solids in the viscosity samples after the gradual waste cooling

\begin{tabular}{|c|c|c|c|}
\hline Sample ID & Particle type & Adhesive to other particles & Adhesive to metal \\
\hline S1 & Very fine crystals & No & Ǹo \\
\hline S2 & Crystals, gel, and a suspended cloud & Yes & No \\
\hline S3 & Packed fine powder & Yes & Yes. \\
\hline S4 & Crystals and a suspended cloud & Slightly & No \\
\hline S5 & Crystals and gel & Yes & Yes \\
\hline S6 & Packed fine powder & Yes & No \\
\hline S7 & Large crystals & Yes & No \\
\hline S8 & Small crystals and gel & Yes & Yes \\
\hline
\end{tabular}

\subsubsection{Viscosity After a Simulated Pump Failure}

After the types of solids were evaluated, the eight samples were reheated to $50^{\circ} \mathrm{C}$ for approximately 1 week. It should be noted that the River Protection Project (RPP) at Hanford has set $50^{\circ} \mathrm{C}$ as the minimum operating temperature for waste transfers. After the equilibration period, the 
height of the solids was measured, and $16 \mathrm{~mL}$ of the hot sample was transferred into the rheometer's small sample adapter, which was also heated to $50^{\circ} \mathrm{C}$. The heat source to the adapter was shut off, and the sample was permitted to cool to ambient temperature in an effort to simulate a pump failure. After $3 \mathrm{~h}$, two viscosity tests were performed in an effort to determine the effects of shear rate and time. The viscosity measurements at a shear rate of $61 \mathrm{~s}^{-1}$ and the volume of settled solids for the tests on simulated pump failures are presented in Table 7.

Table 7. Simulated pump failure: viscosity and volume of gravity-settled solids

\begin{tabular}{ccc}
\hline Sample ID & Viscosity (cP) & Volume of gravity-settled solids (mL) \\
\hline S1 & 1.3 & 0.1 \\
S2 & 2.2 & 0.4 \\
S3 & 2.0 & 0.2 \\
S4 & $46.5^{a}$ & 1.8 \\
S5 & 2.0 & 0.4 \\
S6 & 3.1 & 0.1 \\
S7 & 1.7 & 0.6 \\
S8 & 2.1 & 0.6 \\
\hline
\end{tabular}

${ }^{a}$ Shear rate of $6.1 \mathrm{sec}^{-1}$.

While two samples, $\mathrm{S} 2$ and $\mathrm{S} 5$, formed a high-viscosity gel during the gradual waste cooling, a different sample, S4, formed a high-viscosity gel during the simulated pump failure. The S4 gel contained long needle crystals, which are probably sodium phosphate. The $\mathrm{S} 4$ gel also adhered to metal. With the exception of the S3, S4, and S6 samples, the volumes of gravity-settled solids prior to the simulated pump failure were much smaller than the solid volumes of the samples at $50^{\circ} \mathrm{C}$ during the gradual waste coolings. It should be noted that the S3 and S6 samples contained very little solids at $50^{\circ} \mathrm{C}$ in both tests and that only the $\mathrm{S} 4$ sample had an increase in solids prior to the simulated pump failure. Therefore, the volume of the gravity-settled samples at a particular temperature can be affected by previous heatings and coolings. The impact of previous heatings and coolings was considerably smaller on the viscosities at ambient temperature. With the exception of 
the S4 and S6 samples, the viscosity of the samples after the simulated pump failure were within $0.5 \mathrm{cP}$ of the viscosity obtained during the gradual waste cooling. The viscosity of the $\mathrm{S} 4$ sample increased by $42.9 \mathrm{cP}$ from the gradual waste cooling to the simulated pump failure, while the viscosity of the $\mathrm{S} 6$ sample decreased by $1.2 \mathrm{cP}$ for the same test conditions.

\subsection{DISCUSSION}

Two samples, S2 and S5, formed high-viscosity gels during the gradual waste cooling, while only one sample, S4, formed a high-viscosity gel during the simulated pump failure. The S2 and S5 samples contained high concentrations of phosphate and silicon, and the ionic strength of these two samples was moderate since the total concentration of hydroxide and nitrate was $5 \mathrm{M}$. The $\mathrm{S} 2, \mathrm{~S} 4$, and $\mathrm{S} 5$ samples shared the same high phosphate concentration. While the silicon concentration in the S4 sample was low, the ionic strength in the S4 sample was much higher than in the S2 and S5 samples. The only other sample with a high phosphate concentration was S7. While the S7 sample did contain a large amount of solids, it did not form a gel in these tests. A key difference between the $\mathbf{S} 7$ samples and the other high phosphate samples was the low ionic strength for the $\mathrm{S} 7$ sample. These results indicated that phosphate concentration and ionic strength are the key variables in the formation of plugged pipelines. A high silicon concentration in the presence of a high phosphate concentration may also play an important role in the formation of plugged pipelines. It should be noted that the other components may also be important factors when their concentrations exceed the concentrations in this preliminary investigation. For example, waste operations at Hanford did not permit the transfer of waste until the aluminum concentration was below $1 \mathrm{M}$, even though the nominal solubility of aluminate in a typical Hanford waste solution is $1.3 M$ (McKay, 1993).

These current findings are supported by the results of previous investigations on the line plugs at the Hanford tank farm (Colton et al., 1998). The most commonly identified chemical compound in the Hanford plugs was sodium phosphate needles, which appeared during waste coolings. For the Hanford Tank S-107 cross-site transfer material, the viscosity at a shear rate of $1.2 \mathrm{~s}^{-1}$ increased from $13 \mathrm{cP}$ at $29.5^{\circ} \mathrm{C}$ to $>1916 \mathrm{cP}$ at $24.5^{\circ} \mathrm{C}$ (Delegard, 1980). Future studies will determine the maximum concentrations of phosphate and possibly silicon and the maximum ionic 
strength at which transfer in the event of a pump failure is safe. Later tests will focus on potential secondary factors such as carbonate and higher aluminate concentrations.

These viscosity results support the current RPP transfer policy for the concentration ranges tested. It must be noted that higher concentrations of the key components are found in the Hanford wastes and that additional tests at these higher concentrations and ionic strengths are needed to determine safe transfer conditions. The transfer policy of the RPP assumes that the temperature of the waste will be a minimum of $50^{\circ} \mathrm{C}$ at the start of a waste transfer and that the maximum temperature loss during a transfer is expected to be $10^{\circ} \mathrm{C}$. Since the samples in the gradual-wastecooling experiments did not form a high-viscosity gel until the temperature was below $35^{\circ} \mathrm{C}$, these viscosity results indicated that the RPP policy is reasonable for the concentration ranges tested as long as the temperature of the waste remains above $40^{\circ} \mathrm{C}$. These viscosity results can be used by the RPP to determine if a pump failure will likely lead to a plugged pipeline. Before this determination can be made, it is necessary for the RPP to know the phosphate concentration, ionic strength, and temperature of the waste. Additional information such as solids content and viscosity cannot be used to predict pipeline plugs. After the RPP determines that a particular waste transfer can lead to a plugged line if the transfer is interrupted, the RPP should make provisions to immediately switch to a second pump. The RPP can also use the viscosity and analytical results to determine the requirements for the water flushing after a waste transfer. Problematic wastes should be flushed more thoroughly.

\section{WATER WASHES AND CAUSTIC LEACHES OF SLUDGE FROM TANK S-104}

\subsection{INTRODUCTION}

In 1993, the DOE selected the ESW process as the baseline technology for the pretreatment of Hanford tank sludges. The ESW process uses a series of water washes and caustic leaches to separate soluble nonradioactive components such as aluminum, chromium, phosphate, and silicon from the insoluble radionuclides in the high-level waste sludges. Prior to 1998, nearly all the ESW experimental studies were focused on the effectiveness of the ESW under a single set of test conditions. In FY 1998, the scope of the ESW tests was expanded to examine the effects of 
temperature, time, and sodium hydroxide concentration on the ESW process. The results from the FY 1998 tests on sludge from Tanks BX-112 (Lumetta et al., 1998) and S-101 (Hunt et al., 1998) indicated that reprecipitation can occur during the ESW process. For the tests with sludge from Tank BX-112, the concentrations of aluminum and silicon in the leach solutions decreased as the leaching time was increased, which indicates the formation of insoluble aluminosilicates. In the experiments with sludge from Tank S-101, the leaching process actually increased the dry weights of some of the samples. In contrast to the BX-112 results, the aluminum and silicon concentrations in the S-101 leach solutions increased as the leaching times increased. Therefore, the ultimate fate of the solids from the precipitation process can be very different even though the test conditions for the sludges from Tanks BX-112 and S-101 were very similar. In addition, the formation of aluminosilicates and phosphate gels (Beahm et al., 1997; Beahm et al., 1998) during and after the ESW process can lead to plugged transfer lines.

The primary objectives of the FY 1999 water washes and caustic leaches on a sludge sample from Hanford Tank S-104 were to confirm that solids formation can occur during the leaching step of the ESW process and to identify the newly generated solids. A secondary objective was to determine the impact of a thorough water wash prior to the caustic leach of a Hanford sludge. In FY 1997, several caustic leaches were performed on untreated sludge from Tank S-104 (Egan et al., 1998), and the effectiveness of these leaches varied considerably even though the leach conditions were not significantly different.

\subsection{SLUDGE SAMPLE}

Personnel at the Westinghouse Hanford Company sent approximately $55 \mathrm{~g}$ of sludge from Hanford Tank S-104 to ORNL in March of 1997. Chemical and Analytical Sciences Division (CASD) personnel chemically analyzed approximately $1 \mathrm{~g}$ of the sludge as it was received. During FY 1997, approximately $12 \mathrm{~g}$ of the sludge sample from Hanford Tank S-104 was used in six caustic leaching tests (Egan et al., 1998). The subsequent solids and liquid were chemically analyzed. The results from all of these analyses were reported in detail earlier (Egan et al., 1998). The remainder of the sludge sample was used in the FY 1999 tests on solids formation during the ESW process. 
An earlier Pacific Northwest National Laboratory (PNNL) study (Hill et al., 1995) used waste types and processing histories to qualitatively categorize the Hanford single-shell tanks (SSTs) into characteristic groups. It is expected that the wastes from tanks within a particular group are very similar in chemical content and physical characteristics. Hanford Tank S-104 belongs to Group IV based on the Sort on Radioactive Waste Type (SORWT) model. The high-level waste (HLW) in Tank S-104 is from the reduction/oxidation (REDOX) process. The SORWT Group IV consists of 10 SSTs that contain $1,228,000 \mathrm{~L}$ of sludge, which represents $9.9 \%$ of the total SST sludge volume. The sludge mass and the amounts of key constituents such as aluminum and cesium-137 are shown in Table 8.

Table 8. Hanford Tank S-104: sludge mass and amounts of key constituents

\begin{tabular}{cccccccc}
\hline $\begin{array}{c}\text { Hanford } \\
\text { tank }\end{array}$ & $\begin{array}{c}\text { Total mass } \\
(\mathrm{kg})\end{array}$ & $\begin{array}{c}\text { Aluminum } \\
\text { mass }(\mathrm{kg})\end{array}$ & $\begin{array}{c}\text { Sodium } \\
\text { mass }(\mathrm{kg})\end{array}$ & $\begin{array}{c}\text { Silicon } \\
\text { mass }(\mathrm{kg})\end{array}$ & $\begin{array}{c}\text { Phosphate } \\
\text { mass }(\mathrm{kg})\end{array}$ & $\begin{array}{c}{ }^{137} \mathrm{Cs} \text { activity } \\
(\mathrm{Bq})\end{array}$ & $\begin{array}{c}{ }^{90} \mathrm{Sr} \text { activity } \\
(\mathrm{Bq})\end{array}$ \\
\hline $\mathrm{S}-104^{a}$ & $1.66 \mathrm{E} 6$ & $1.96 \mathrm{E} 5$ & $1.98 \mathrm{E} 5$ & $2.43 \mathrm{E} 3$ & $4.8 \mathrm{E} 2$ & $3.89 \mathrm{E} 15$ & $1.87 \mathrm{E} 16$ \\
\hline \multicolumn{6}{c}{ Colton, 1996.} \\
\hline
\end{tabular}

\subsection{EXPERIMENTAL PROCEDURE}

The experimental procedures to wash the entire sludge sample, to divide the washed sludge into aliquots, and to leach and wash the individual aliquots have been described in detail previously (Hunt et al., 1998). The only significant change involved enhancements to the procedure to validate the uniformity of the aliquots. The cesium- 137 concentration and the ratio of the weight of the decanted liquid to weight of washed solids were determined for each sample, and all of the results were within $2 \%$ of the average value. Portions of several samples were dried at $105^{\circ} \mathrm{C}$ until a constant weight was achieved, and the percentage of water in each sample varied by less than $1 \%$. These results indicate that the ORNL procedure produces uniform sample aliquots.

\subsection{RESULTS}




\subsubsection{Water Washes}

The goal of the water washes is to remove all of the water-soluble salts. In this study, inhibited water was used to wash the sludge sample from Hanford Tank S-104. The first three washes were performed at room temperature, whereas the sludge sample was heated to $90^{\circ} \mathrm{C}$ for the other two washes. Approximately $170 \mathrm{~mL}$ of inhibited water, which consists of $0.01 \mathrm{M}$ sodium hydroxide and $0.01 \mathrm{M}$ sodium nitrite, was used in each of the washes. At the end of each wash, the sample was centrifuged, and the wash solution was decanted. The initial weight of the sludge sample was $40.34 \mathrm{~g}$. The experimental conditions and results of the five water washes are shown in Table 9.

Table 9. Inhibited water washes of sludge from Hanford Tank S-104

\begin{tabular}{|c|c|c|c|c|c|c|}
\hline Wash & $\begin{array}{c}\text { Temperature } \\
\left({ }^{\circ} \mathrm{C}\right)\end{array}$ & $\begin{array}{l}\text { Mixing } \\
\text { time (h) }\end{array}$ & $\begin{array}{c}\text { Weight of water } \\
\text { added }(\mathrm{g})\end{array}$ & $\begin{array}{l}\text { Type of } \\
\text { mixing }\end{array}$ & $\begin{array}{l}\text { Weight of wet } \\
\text { solids }(\mathrm{g})\end{array}$ & $\begin{array}{l}\text { Weight increase from } \\
\text { initial sample (\%) }\end{array}$ \\
\hline 1 & $\begin{array}{c}\text { Room } \\
\text { temperature }\end{array}$ & 23.5 & 168.81 & $\begin{array}{l}\text { End over } \\
\text { end }\end{array}$ & 49.79 & 23.4 \\
\hline 2 & $\begin{array}{c}\text { Room } \\
\text { temperature }\end{array}$ & 18 & 172.95 & $\begin{array}{l}\text { End over } \\
\text { end }\end{array}$ & 48.88 & 21.1 \\
\hline 3 & $\begin{array}{l}\text { Room } \\
\text { temperature }\end{array}$ & 120 & 173.12 & $\begin{array}{l}\text { End over } \\
\text { end }\end{array}$ & 56.16 & 39.2 \\
\hline 4 & 90 & 1 plus & 170.72 & Rocked & 53.82 & 33.4 \\
\hline 5 & 90 & 1 plus & 170.68 & $\begin{array}{l}\text { Magnetic } \\
\text { stir bar }\end{array}$ & 51.45 & 27.5 \\
\hline
\end{tabular}

At the conclusion of the five water washes, the wet solids weighed $27.5 \%$ more than the original sludge sample. It is apparent that the initial sludge sample was dehydrated and that the rehydration process in a tank with a dehydrated sludge and limited mixing capabilities can be very slow. Even though the sample gained weight, the water washes were still effective in removing water-soluble salts. The moisture content of the original sludge sample was $15.6 \%$ on a weight percent basis, so the dry weight of initial sample was $34.05 \mathrm{~g}$. At the end of water washes, the dry weight of the washed solids was $15.32 \mathrm{~g}$. Therefore, the water washes removed $18.73 \mathrm{~g}$ of watersoluble salts. 


\subsubsection{Caustic Leaches}

Twelve of the 20 aliquots were used in the tests to determine if solid formation occurs during the ESW process. The leach conditions for each aliquot of washed sludge are summarized in Table 10. The leaching time, temperature, and sodium hydroxide concentration for the first ten experiments were selected from conditions, which were used in FY 1998 studies (Hunt et al., 1998). Equilibrium calculations were used to determine the amount of sodium hydroxide to be used in the first ten tests. The amounts of sodium, nitrate, hydroxide, aluminate, and aluminum hydroxide after each processing step were calculated. The results for the four leach conditions are as follows: (1) $42.7 \mathrm{~mL}$ of sodium hydroxide per gram of initial sludge solids with $1 \mathrm{M}$ sodium hydroxide at $70^{\circ} \mathrm{C}$, (2) $25.3 \mathrm{~mL}$ of sodium hydroxide per gram of initial sludge solids with $1 \mathrm{M}$ sodium hydroxide at $95^{\circ} \mathrm{C}$, (3) $13.3 \mathrm{~mL}$ of sodium hydroxide per gram of initial sludge solids with $3 \mathrm{M}$ sodium hydroxide at $70^{\circ} \mathrm{C}$, and (4) $8.0 \mathrm{~mL}$ of sodium hydroxide per gram of initial sludge solids with $3 \mathrm{M}$ sodium hydroxide at $95^{\circ} \mathrm{C}$. The calculated amounts of sodium hydroxide were increased by $50 \%$ in the actual experiments to account for uncertainties associated with the calculations. The results from the FY 1997 caustic leaches of the sludge from Hanford Tank S-104 (Egan et al., 1998) were used to select the final two leach conditions. In FY 1997, six samples of untreated sludge from Tank S-104 were leached with 3.8-6.3 M sodium hydroxide and then washed with inhibited water. In five of the six tests, the sludge residue after the caustic leach and water washes weighed more than the initial sludge sample (Egan et al., 1998). The conditions that produced the two largest weight gains were repeated in this study. For each leach condition, the sample's dry weights before and after the ESW process are given in Table 10.

\subsection{DISCUSSION}

\subsubsection{Water Washes}

In the earlier water washes with sludges from Tanks S-101 and C-103, the weight of the wet solids decreased with each subsequent wash (Hunt et al., 1998). This trend in weight loss indicates 
Table 10. Leach conditions and mass changes for the washed sludge solids from Tank S-104

\begin{tabular}{lccccccc}
\hline $\begin{array}{c}\text { Sample } \\
\text { ID }\end{array}$ & $\begin{array}{c}{[\mathrm{NaOH}]} \\
(M)\end{array}$ & $\begin{array}{c}\text { Leach } \\
\text { temp } \\
\left({ }^{\circ} \mathrm{C}\right)\end{array}$ & $\begin{array}{c}\text { Leach } \\
\text { time } \\
(\mathrm{h})\end{array}$ & $\begin{array}{c}\mathrm{NaOH} \\
\text { added } \\
(\mathrm{g})\end{array}$ & $\begin{array}{c}\text { Dry weight: } \\
\text { washed } \\
\text { solids }(\mathrm{g})\end{array}$ & $\begin{array}{c}\text { Dry weight: } \\
\text { solids after } \\
\text { ESW }(\mathrm{g})\end{array}$ & $\begin{array}{c}\text { Weight change } \\
\text { due to caustic } \\
\text { leaching }(\%)\end{array}$ \\
\hline $1-70-5$ & 1 & 70 & 5 & 222.9 & 1.287 & 1.289 & 0.2 \\
$1-70-24$ & 1 & 70 & 24 & 219.7 & 1.275 & 1.098 & -13.9 \\
$1-70-168$ & 1 & 70 & 168 & 220.1 & 1.276 & 0.586 & -54.1 \\
$3-70-5$ & 3 & 70 & 5 & 75.44 & 1.314 & 1.536 & 16.9 \\
$3-70-24$ & 3 & 70 & 24 & 74.56 & 1.296 & 1.103 & -14.9 \\
$3-70-168$ & 3 & 70 & 168 & 74.75 & 1.291 & 0.601 & -53.5 \\
$1-95-5$ & 1 & 95 & 5 & 128.1 & 1.249 & 0.971 & -22.3 \\
$3-95-5$ & 3 & 95 & 5 & 32.32 & 1.313 & 0.882 & -32.8 \\
$4-70-21 \mathrm{a}$ & 4 & 70 & 20.8 & 16.40 & 0.803 & 0.667 & -16.8 \\
$4-70-21 \mathrm{~b}$ & 4 & 70 & 20.8 & 25.54 & 0.652 & 0.589 & -9.7 \\
\hline
\end{tabular}

that each subsequent water wash was becoming less effective at the removal of water-soluble salts. This result was confirmed by conductance measurements and cesium-137 activities. However, the results of the water washes with sludge from Tank S-104 did not follow the same weight loss trend because the sludge sample was very dehydrated. In fact, the wet solids gained weight through the third water wash, and the wet solids weighed $3.3 \%$ more after the final wash than after the first wash. These results indicate that the rehydration process can be very slow. In sharp contrast to the unpredictable weight changes with the sludge from Tank S-104, the gamma activity, which was primarily due to cesium-137, decreased with each subsequent wash. Therefore, the cesium-137 activity can be used to follow the progress of the water washes even if the tank sludges are dehydrated. It is expected that a conductance probe would also be an effective process control tool.

The test results indicate that four to six water washes of the sludge samples from Tanks S-101, S-104, and C-104 were needed to remove essentially all of the water-soluble salts. Even though approximately $60 \%$ of the water-soluble salts can be removed during the first wash, the remaining soluble salts in the sludge can have a direct impact on the performance of the ESW process if the salts are not removed prior to the caustic leaching. The remaining soluble salts will 
lead to a higher ionic strength in the leach solutions. Ionic strength has a direct impact on the solubilities of aluminum, phosphate, silicon, and sodium. Simulant tests have demonstrated that rate of natrophosphate $\left[\mathrm{Na}_{7}\left(\mathrm{PO}_{4}\right)_{2} \mathrm{~F} \cdot 19 \mathrm{H}_{2} \mathrm{O}\right]$ formation increases significantly as the concentration of sodium nitrate increases. The presence of nitrate in the leach solution can also lead to the formation of different types of sodium aluminosilicates such as cancrinite. A cancrinite plug at Savannah River shut down its $242-16 \mathrm{H}$ evaporator system. It should be noted that most of the caustic leaches in the ESW tests were performed on partial washed sludge samples, which may be quite reasonable if the user does not wash the sludge after the retrieval process. However, the wash factors are based on 0.1 - to $0.3-\mathrm{g}$ sludge samples, which were thoroughly washed. The differences in the wash procedures could lead to erroneous wash factors or leach factors. It is clear that the initial ESW test conditions were not designed to mimic full-scale remediation.

\subsubsection{Caustic Leaches}

\section{Newly Generated Solids}

As shown in Table 10, the dry weights of the 1-70-5 and 3-70-5 samples increased after the washed solids were leached with sodium hydroxide and washed with inhibited water. The small dry weight gain for 1-70-5 is not large enough to confirm the formation of solids during the caustic leaching process. However, the dry weight gain of $16.9 \%$ for the $3-70-5$ sample greatly exceeds the experimental uncertainties. Therefore, this result confirms the FY 1998 finding that solids can and do form during caustic leaching. Attempts to identify the new solids with X-ray diffraction and scanning electron microscopy have been delayed indefinitely due to a change in program guidance. However, the chemical analysis of previous ESW tests can be used to identify the elements in the newly generated solids. A comprehensive analysis of all the ESW results determined that water washes and caustic leaches primarily affect aluminum, cesium, chromium, sodium, silicon, and phosphate. Since the sludge residue increased in mass during the caustic leaching, the newly generated solids must contain component(s) from the leach solution, which are hydroxide, sodium, and water. In the FY 1997 tests on sludge from Tank S-104, nearly all the chromium and cesium-137 were found in the leach solutions, so the newly generated solids do not contain 
appreciable amounts of chromium or cesium. Therefore, the newly generated solids probably contain aluminum, hydroxide, sodium, silicon, phosphate, and/or water. Previously, this research effort has observed the formation of solids in filtered leachates (Beahm et al., 1997). Scanning electron microscopy and X-ray diffraction were used to identify the precipitates as natrophosphate and sodium silicates. The ESW tests on sludge from Tank BX-112 indicated that sodium aluminosilicates formed during the caustic leaches (Lumetta et al., 1998). The formation of natrophosphate during this current study is not likely because the fluoride concentration in the untreated sludge was below the detection limit of $293 \mu \mathrm{g} / \mathrm{g}$. The FY 1997 leach results on the sludge from Tank S-104 strongly suggest that silicon is part of the newly generated solids. The concentration of aluminum in the untreated sludge sample from Tank S-104 was considerably higher than the concentration of silicon. Since the conversion of silicon to sodium silicates cannot account for a majority of the weight gain for the 3-70-5 sample, most of the newly generated solids are probably sodium aluminosilicates.

\section{Effects of Small Changes in the Process Conditions}

The wide variability in the results from the FY 1997 caustic leach tests on untreated sludge from Tank S-104 (Egan et al., 1998) has not received a great deal of attention. The leach conditions and results from the FY 1997 (unwashed) and FY 1999 (washed) tests on sludge from Tank S-104 are presented in Table 11. Even though the leach conditions for samples 2, 3, and 4 were very similar, the aluminum removal results clearly show that small changes in the process conditions can dramatically affect the performance of the caustic leaches (Egan et al., 1998). . The trend in aluminum removal is supported by the overall trends in percent weight change and density of the leachate. As aluminum is leached from the sludge, the mass of the remaining sludge should become smaller, and the density of the leachate should increase. Since the relationships among the percent weight change, the density of the leachate, and aluminum removal are in general agreement, the differences in the effectiveness of the caustic leaches appear to be real. It should also be noted that the FY 1999 leach results for samples 1-70-5 and 3-70-5 exhibited considerable variability, which was reduced significantly at $24-$ and $168-\mathrm{h}$ samples. This variability in the initial dissolution rates will significantly hamper the development of a kinetic model. 
Table 11. FY 1997 and FY 1999 leach conditions and results for sludge from Tank S-104

\begin{tabular}{ccccccccc}
\hline $\begin{array}{c}\text { Sample } \\
\text { ID }\end{array}$ & $\begin{array}{c}\text { Washed } \\
\text { before } \\
\text { leach }\end{array}$ & $\begin{array}{c}{[\mathrm{NaOH}]} \\
(M)\end{array}$ & $\begin{array}{c}\text { Leach } \\
\text { temp } \\
\left({ }^{\circ} \mathrm{C}\right)\end{array}$ & $\begin{array}{c}\text { Leach } \\
\text { time } \\
(\mathrm{h})\end{array}$ & $\begin{array}{c}\text { Liquid: } \\
\text { solids }^{a} \\
(\mathrm{~mL} / \mathrm{g})\end{array}$ & $\begin{array}{c}\text { \% Weight } \\
\text { change }^{b} \\
(\%)\end{array}$ & $\begin{array}{c}\text { Aluminum } \\
\text { removal } \\
(\%)\end{array}$ & $\begin{array}{c}\text { Density of } \\
\text { leachate } \\
(\mathrm{g} / \mathrm{mL})\end{array}$ \\
\hline 2 & No & 3.8 & 67 & 24 & 9.08 & 30 & 50.3 & 1.273 \\
3 & No & 3.99 & 70 & 20.8 & 5.81 & 165 & 20.4 & 1.189 \\
4 & No & 3.99 & 70 & 20.8 & 11.93 & 229 & 20.8 & 1.166 \\
5 & No & 6.33 & 70 & 21 & 11.77 & 83 & 26.6 & 1.230 \\
$4-70-21 \mathrm{a}$ & Yes & 4 & 70 & 20.8 & 5.81 & 46 & $c$ & $c$ \\
$4-70-21 \mathrm{~b}$ & Yes & 4 & 70 & 20.8 & 11.93 & 44 & $c$ & $c$ \\
\hline
\end{tabular}

${ }^{a} \mathrm{Volume}$ of $\mathrm{NaOH}$ in milliliters divided by the dry weight of the untreated sludge in grams.

${ }^{b}[($ Wet weight of the leached and washed sludge sample in grams divided by the weight of the untreated sludge in grams) minus 1] times 100.

Not measured.

\section{Need for Initial Water Washes}

The experimental conditions for samples 4-70-21a and 4-70-21b were selected to mimic the conditions for samples 3 and 4, which exhibited the largest percent weight gain in FY 1997 study (Egan et al., 1998). The only difference between the FY 1997 and FY 1999 tests is that the FY 1997 samples were untreated before the leach, while the FY 1999 samples were thoroughly washed before the caustic leaches. The percent weight increases for samples 4 and 5 were larger than their FY 1999 counterparts by 119 and $185 \%$, respectively. Apparently, the presence of water-soluble salts in the FY 1997 tests led to additional solids formations, which did not occur in the FY 1999 tests. The differences in the percent weight change for samples 3 and 4 and for samples 4-70-21 a and 4-70-21b were $64 \%$ and $2 \%$, respectively. This difference may indicate that the effectiveness of the caustic leach may be more impacted by small changes in the process conditions if the water-soluble salts are present during the leaches. It should be noted that the percent weight changes on a dry weight basis for samples 4-70-21a (-16.8\%), 4-70-21b (-9.7\%), and 3-70-24 (-14.9\%) were comparable. The reduction in sludge mass with less variability in the effectiveness of the caustic leaches clearly illustrates the advantages of a thorough water wash prior to the caustic leach. 


\section{CHEMICAL SIMULANT OF THE SODIUM PHOSPHATE PLUG}

The following information was provided to the participants in the university contest on the removal of a pipeline plug.

\section{Problem Statement}

The goal is to create a process to remove the plug from the pipe without damage to the pipe. The method should be nonhazardous to the operator.

\section{Design Considerations}

- No mechanical intrusion or external access that exceeds more than $1 \mathrm{ft}$ from the end of the access pipe will be permitted.

- Applied pressure will be limited to $50 \mathrm{psi}$ to prevent pipe rupture.

- The temperature of the system should not exceed $50^{\circ} \mathrm{C}$ at any point.

- All chemical processes must be demonstrated during the lab-scale tests to prove the safety of the process before it is applied to the pipe system.

- The liquid in the pipe above the plug may be adjusted or replaced.

- Force may be applied to one end of the pipe to the extent that the pipe is not broken.

\section{Evaluation Criteria}

- Each team is advised to read the Team Guide and Team Handbook for a comprehensive understanding of the contest evaluation criteria.

- Appropriate Material Safety Data Sheets (MSDS) should be available during the demonstration.

- The pipeline will be visually inspected for plug removal. Although complete removal is desirable, partial removal of the plug will also be considered a success.

\section{Supplemental Information}

The plug will be installed in the following manner:

1. The test section walls will be coated with sticky natrophosphate. 
2. The test section walls will then be coated with a hot sodium phosphate solution which will form needles as the solution is cooled to ambient temperature.

3. The test section will be allowed to age for a minimum of 1 week to enhance the growth of the needle crystals.

4. The test section will be attached to the lead-in pipe section.

5. The apparatus will be filled to the mouth of the pipe with $0.01 M$ sodium hydroxide. The mouth of the pipe will have a plastic pipe thread to interface with the unplugging equipment.

\section{$\underline{\text { Removal Technologies Evaluated }}$}

The nine universities in the contest evaluated a wide range of chemical and physical methods to remove the simulated pipeline plugs. These technologies included an air hammer, electrolysis, evacuation with a solar tent, freezing, a laser, a magnetic stirrer, a mechanical auger, resistance heating, ultrasonic waves, and a water hammer. Several chemical additions were also proposed. Most of the chemical additions involved acid treatment. Since the solubility of the natrophosphate increases significantly below a $\mathrm{pH}$ of 8 , the use of acetic acid, boric acid, citric acid, formic acid, hydrochloric acid, oxalic acid, phosphoric acid, and sulfuric acid was evaluated by the students. Other chemical additions included aluminum nitrate, sodium bisulfate, surfactants, and zinc.

\section{Future Activities}

The Retrieval Program of the Tanks Focus Area has requested that this task formulate a new chemical plug for the next university contest. This new formulation will simulate the plug, which occurred during the transfer of waste from Tank SX-104. In addition, this task will evaluate chemical methods to remove the simulated plugs.

\section{ALUMINOSILICATE FORMATION}

\subsection{INTRODUCTION}


Silicates are present in many of the liquid wastes at Hanford and Savannah River. By themselves silicates are quite soluble in highly alkaline solutions. However, in the presence of various metals, the silicates solubility decreases substantially due to the formation of complicated minerals such as kaolinite and cancrinite. These precipitations also decrease the solubility of metals such as aluminum, which would interfere with most waste strategies. Therefore, it is important to understand silicate chemistry and to incorporate it into predictive models, which will describe tank contents and processing options.

\subsection{MODELING ALUMINOSILICATE FORMATION}

It is well known that the solubilities of both quartz and amorphous silica increase as the solution alkalinity increases above a pH of 8 (Iler, 1979). This solubility effect is true in pure hydroxide solutions (Alexander et al., 1954) and in the presence of other salts (Zarubin et al., 1990). In $3 \mathrm{~m}$ sodium hydroxide, the solubility of amorphous silica is greater than $4 \mathrm{~mol} / \mathrm{kg}$. It is also understood that considerable polymerization of the silicate species occurs in the $\mathrm{pH}$ range of 10.8 to 12.2 . However, very little polymerization occurs in alkaline solutions outside this $\mathrm{pH}$ range. Above a $\mathrm{pH}$ of 12.2 , solutions become very viscous since polymerization declines as solubility continues to increase. Therefore, a high silica content could pose problems with waste processing.

Aluminum solids are generally gibbsite or boehmite. Their solubility increases as solution alkalinity increases due to formation of the aluminate ion. Thus, in a $3 m$ sodium hydroxide solution at $25^{\circ} \mathrm{C}$, approximately $0.34 \mathrm{~mol} / \mathrm{kg}$ of aluminum should be dissolved in solution. In sodium hydroxide solutions of $1 \mathrm{~m}$ and $0.1 \mathrm{~m}$, the aluminum solubilities drop to 0.09 and $0.009 \mathrm{~mol} / \mathrm{kg}$, respectively. In the presence of other nonreactive salts such as sodium nitrate, sodium chloride, sodium fluoride, and sodium nitrite, there is a small ionic strength effect which lowers solubility. However, the aluminum solubility can still be quite high if sufficient caustic is present.

It would seem reasonable to suspect that alkaline solutions containing aluminum and silicon would have high solubility since individual components have high solubilities. However, the solubility decreases drastically when both components are present, as shown in Fig. 1. If even a trace quantity of either component is present, the solubility of both drops by several orders of 
magnitude. The pure component inventories of silicon on the left and aluminum on the right are plotted as squares.

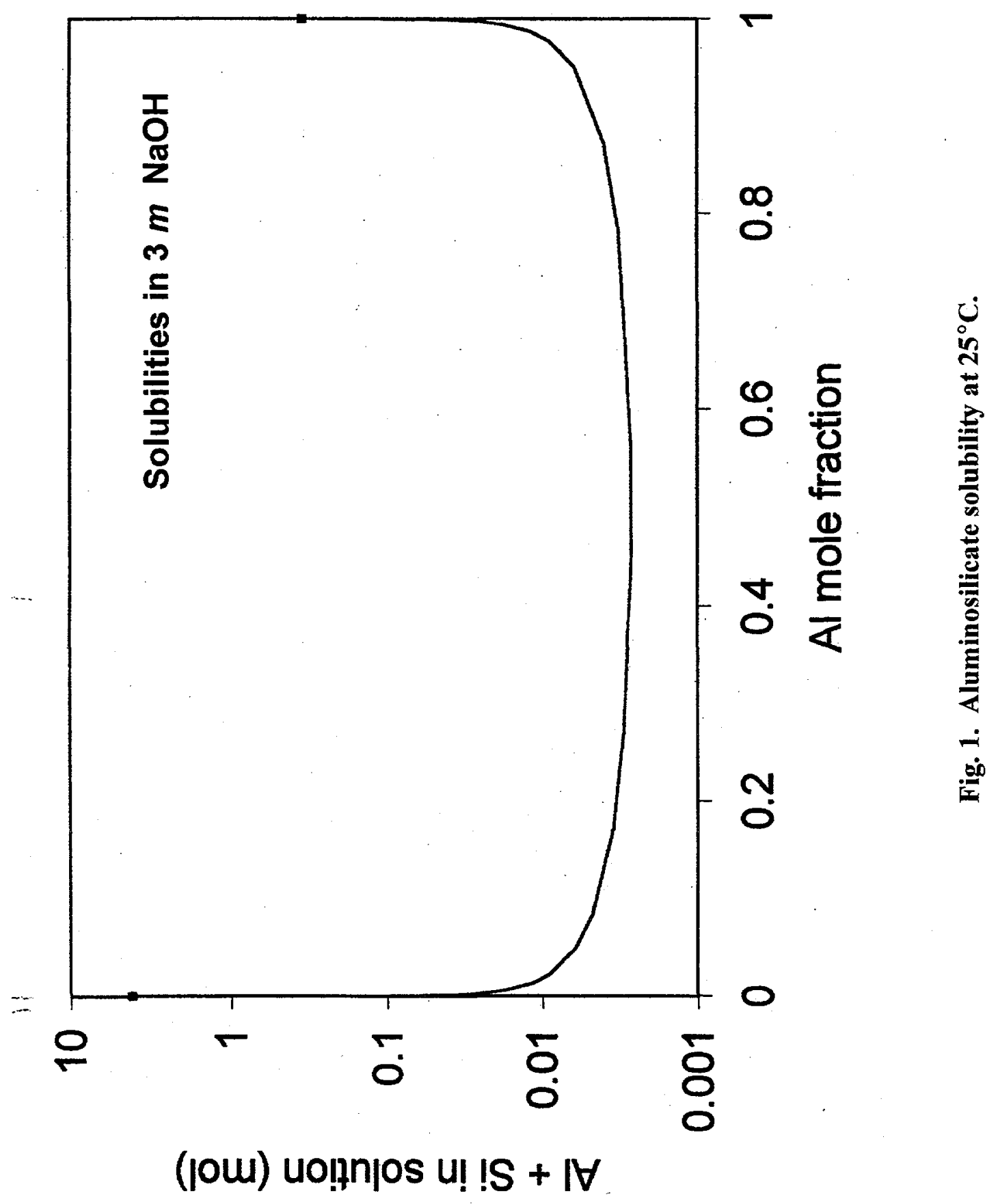


This behavior is caused by the formation of complex minerals involving both aluminum and silicon. These solids also may contain water of hydration and various anions. The three aluminosilicate minerals are currently included in our modeling work even though their properties are somewhat uncertain:

Nepheline $\mathrm{NaAlSiO}_{4}$

Kaolinite

$$
\mathrm{Al}_{2} \mathrm{O}_{3} \cdot 2 \mathrm{SiO}_{2} \cdot \mathrm{H}_{2} \mathrm{O}
$$

Cancrinite

$$
\mathrm{Na}_{7.68} \mathrm{Al}_{6} \mathrm{Si}_{6} \mathrm{O}_{24}\left(\mathrm{NO}_{3}\right)_{1.68}\left(\mathrm{H}_{2} \mathrm{O}\right)_{4.1} \text {. }
$$

In Fig. 1, the decrease in solubility is due to formation of nepheline. However, if $\mathrm{NaNO}_{3}$ is available, then the solid is probably cancrinite.

In order to effectively model aluminosilicate formation, it is of course necessary to first model the separate systems $\mathrm{Na}-\mathrm{Al}-\mathrm{OH}-\mathrm{NO}_{3}$ and $\mathrm{Na}-\mathrm{Si}-\mathrm{OH}-\mathrm{NO}_{3}$. The former has been done previously, and the results have been used in these current calculations. The latter is a much more complicated system, and the current study is an attempt to model the simpler system $\mathrm{Na}-\mathrm{Si}-\mathrm{OH}$ at $25^{\circ} \mathrm{C}$. The details of this work are included in Appendix A, and refinement is still in progress. Ongoing studies are attempting to extend the capability to higher temperatures.

\section{ACKNOWLEDGMENTS}

This task was sponsored by the U.S. Department of Energy through the Office of Science and Technology's Tanks Focus Area under U.S. Government contract DE-AC05-96OR22464 with Lockheed Martin Energy Research Corporation. This work was performed at the Oak Ridge National Laboratory under the auspices of the Chemical Technology Division.

\section{REFERENCES}

G. B. Alexander, W. M. Heston, and R. K. Mler. 1954. "The Solubility of Amphorous Silica in Water," J. Phys. Chem., 58, 453.

E. C. Beahm, C. F. Weber, T. A. Dillow, S. A. Bush, S. Y. Lee, and R. D. Hunt. 1997. Sludge Treatment Studies, ORNL/TM-13371, Oak Ridge National Laboratory, Oak Ridge, Tennessee. 
E. C. Beahm, C. F. Weber, D. D. Lee, T. A. Dillow, R. D. Hunt, C. M. Keswa, K. Osseo-Asare, and K. E. Spear. 1998. Status Report on Solid Control in Leachates, ORNL/TM-13660, Oak Ridge National Laboratory, Oak Ridge, Tennessee.

N. G. Colton. 1996. Status Report: Pretreatment Chemistry Evaluation-Wash and Leach Factors for the Single-Shell Tank Waste Inventory, PNNL-11290, Pacific Northwest National Laboratory, Richland, Washington.

N. G. Colton, E. A. Daymo, W. L. Kuhn, and A. R. Felmy. 1998. Literature Review: Events, Phenomena, and Studies Pertinent to Technical Risks in the Waste Feed Delivery Project, Pacific Northwest National Laboratory, Richland, Washington.

C. H. Delegard. 1980. Viscosity/Cooling Data for Tanks 107-S and 105-BXWaste Liquors, Internal Memo \#65124-068-80, Rockwell International, Richland, Washington.

B. Z. Egan, B. B. Spencer, and C. W. Chase. 1998. Caustic Leaching of Sludges from Selected Hanford Tanks, ORNL/TM-13500, Oak Ridge National Laboratory, Oak Ridge, Tennessee.

D. L. Herting. 1980. "Evaporator Feeds High in Phosphate," Internal Letter \#65453-80-296, Rockwell Hanford Operations, Richland, Washington.

J. G. Hill; G. S. Anderson, and B. C. Simpson. 1995. The Sort on Radioactive Waste Type Model: A Method to Sort Single-Shell Tanks into Characteristic Groups, PNNL-9814, Rev. 2, Pacific Northwest National Laboratory, Richland, Washington.

R. D. Hunt, J. L. Collins, and C. W. Chase. 1998. Water Washes and Caustic Leaches of Sludge from Hanford Tank S-101 and Water Washes of Sludge from Hanford Tank C-103, ORNL/TM-13655, Oak Ridge National Laboratory, Oak Ridge, Tennessee.

R. K. Iler. 1979. The Chemistry of Silica, Wiley, New York.

G. J. Lumetta, B. M. Rapko, J. Liu, D. J. Temer, and R. D. Hunt. 1998. Washing and Caustic Leaching of Hanford Tank Sludge: Results of FY 1998 Studies, PNNL-12026, Pacific Northwest National Laboratory, Richland, Washington.

R. L. McKay. 1993. Letter Report for Westinghouse Hanford Company: TWRS Retrieval Technology Project, Slurry Transport - Plugging Investigation, Pacific Northwest National Laboratory, Richland, Washington.

A. Shekarriz, Y. Onishi, P. A. Smith, M. Sterner, D. R. Rector, and J. Virden. 1997. Cross-Site Transfer System at Hanford: Long-Term Strategy for Waste Acceptance, PNNL-11497, Pacific Northwest National Laboratory, Richland, Washington.

D. P. Zarubin and N. V. Menkina. 1990. "The Solubility of Amphorous Silica in an Alkaline Aqueous Media at a Constant Ionic Strength," Russ. J. Inorg. Chem., 35(1), 16. 
APPENDIX A

MODEL FOR THE SOLUBILITIES OF SILICATE SPECIES

\author{
C. F. Weber
}

A-1 
. 


\section{A.1 SILICATE HYDROLYSIS}

In aqueous solutions, the hydrolysis of solid silica occurs and forms monomeric silicic acid, as shown in Eq. (1).

$$
\mathrm{SiO}_{2}+2 \mathrm{H}_{2} \mathrm{O} \leftrightarrow \mathrm{Si}(\mathrm{OH})_{4}
$$

Dimerization joins two silicon atoms through a common bond with an oxygen atom and releases one water molecule, as illustrated in Eq. (2).<smiles></smiles>

Additional polymerization occurs through analogous bonding of multiple $\mathrm{OH}$ groups which form chains, rings, or three-dimensional structures. Many of these shapes have been identified through NMR spectroscopy and other techniques. The hydroxyl groups can also form silicate anions, as shown in Eqs. (3) and (4).

$$
\begin{aligned}
\mathrm{Si}(\mathrm{OH})_{4} & \leftrightarrow \mathrm{H}^{+}+\mathrm{SiO}(\mathrm{OH})_{3}{ }^{-} \\
\mathrm{SiO}(\mathrm{OH})_{3}{ }^{-} & \leftrightarrow \mathrm{H}^{+}+\mathrm{SiO}_{2}(\mathrm{OH})_{2}{ }^{2-}
\end{aligned}
$$

As alkalinity increases, ionization also increases. To simplify terminology, the notation displayed in Eq. (5) was adopted to represent the polymeric species.

$$
(\mathrm{i}, \mathrm{j})=\mathrm{Si}_{\mathrm{j}} \mathrm{O}_{m}(\mathrm{OH})_{n}^{\mathrm{i}-},
$$

where $m$ and $n$ vary according to the bonding arrangements of the various species. Several common examples are shown in Table A.1.

The processes of dissolution, polymerization, and ionization create a tremendously complicated system in which hundreds of individual species may exist. Modeling such a system requires simplification, empiricism, and even heuristic reasoning. It is desirable to integrate silicate behavior with other electrolyte components, which are modeled using Pitzer's ion interaction treatment.

As seen from the examples in Table A.1, each silicon atom is connected via an oxygen bridge to as many as four other silicon atoms. NMR measurements generally determine the presence of these different connectivity types, labeled $\mathrm{Q}^{0}, \mathrm{Q}^{1}, \mathrm{Q}^{2}, \mathrm{Q}^{3}$, and $\mathrm{Q}^{4}$. For example, $\mathrm{Q}^{0}$ represents the 


\begin{tabular}{|c|c|c|}
\hline Name & Formula $^{a}$ & Structure $^{b}$ \\
\hline Dimer & {$\left[\mathrm{Si}_{2} \mathrm{O}_{1+n}(\mathrm{OH})_{\mathrm{k}-n}\right]^{n-}$} & $\mathrm{HO}-\underset{\mathrm{OH}}{\mathrm{OH}}-\mathrm{O}-\stackrel{\mathrm{OH}}{\mathrm{Si}_{\mathrm{OH}}}-\mathrm{OH}$ \\
\hline Linear trimer & {$\left[\mathrm{Si}_{3} \mathrm{O}_{2+n}(\mathrm{OH})_{\mathrm{E-n}}\right]^{n-}$} & $\mathrm{Si}-\mathrm{Si}-\mathrm{Si}$ \\
\hline Linear tetramer & {$\left[\mathrm{Si}_{4} \mathrm{O}_{3+n}(\mathrm{OH})_{10-n}\right]^{n-}$} & $\mathrm{Si}-\mathrm{Si} \longrightarrow \mathrm{Si}-\mathrm{Si}$ \\
\hline Cyclic trimer & {$\left[\mathrm{Si}_{3} \mathrm{O}_{3+n}(\mathrm{OH})_{6-n}\right]^{n-}$} & \\
\hline Cyclic tetramer & {$\left[\mathrm{Si}_{4} \mathrm{O}_{4+n}(\mathrm{OH})_{B-n}\right]^{n-}$} & \\
\hline Prismatic hexamer & {$\left[\mathrm{Si}_{8} \mathrm{O}_{9+n}(\mathrm{OH})_{G-n}\right]^{n-}$} & \\
\hline Prismatic octamer & {$\left[\mathrm{Si}_{8} \mathrm{O}_{12+n}(\mathrm{OH})_{8-n}\right]^{n-}$} & \\
\hline Generic polymer & $\left(\mathrm{SiO}_{2}\right)_{j}$ & \\
\hline
\end{tabular}

${ }^{a} n=0,1,2, \ldots$

${ }^{b}$ Except for dimer, all oxygen linkages are denoted by lines. If not shown, silicon atoms occur at vertices. $\mathrm{OH}$ and $\mathrm{O}^{-}$groups are not shown except for dimer.

total inventory of species in which no silicon atom is bonded to another. The dimer and end groups of other linear molecules comprise the $Q^{1}$ group, and $Q^{4}$ represents large polymers in which virtually every silicon atom connects to another. This could also represent the amorphous silica precipitate. Interior atoms of linear molecules and the cyclic species correspond to $Q^{2}$, where each silicon atom is connected to two others. However, the sharp bond angles in the cyclic trimer produce a separate signal, which is denoted as $\mathrm{Q}^{2} \Delta$. Analogously, the connectivity groups $\mathrm{Q}^{3}$ and $\mathrm{Q}^{3} \Delta$ correspond to bonds such as those in the prismatic octamer and hexamer, respectively. Sometimes it is possible for the NMR signal to distinguish minor differences within connectivity groups. However, the uncertainty of such determinations does not justify the extra modeling effort. Therefore, this study was only concerned with the following basic connectivity groups: $Q^{0}, Q^{1}, Q^{2}, Q^{2} \Delta, Q^{3}, Q^{3} \Delta$, and $Q^{4}$. 


\section{A.2 SOLUBILITIES IN NEUTRAL SALT SOLUTIONS}

Silicic acid is sparingly soluble near neutral $\mathrm{pH}$, and this is affected slightly by the presence of other ions. These effects were measured for many common salt solutions (Marshall, 1980; Marshall et al., 1980), and some of the results are listed in Table A.2. This effect can be incorporated into the Pitzer model through the coefficients $\lambda_{i j}$, which describe interactions between ions and neutral species. Using data from Table A.2, these parameters have been determined through nonlinear leastsquares estimation and are listed in Table A.3.

Table A.2. Experimental values on the solubilities of silicates

\begin{tabular}{|c|c|c|c|c|}
\hline Reference & Type of data & $\mathrm{pH}$ range & Data points & $\max I(\mathrm{~m})$ \\
\hline Alexander et al., 1954 & Solubility in $\mathrm{NaOH}$ & $8-10.7$ & 12 & 0.1 \\
\hline \multirow[t]{2}{*}{ Zarubin et al., 1990} & Solubility in $\mathrm{NaOH}+1 \mathrm{MNaCl}$ & $9-10.7$ & 18 & 1 \\
\hline & $+3 \mathrm{MNaCl}$ & $8.8-10.3$ & 14 & 3 \\
\hline \multirow[t]{3}{*}{ Marshall et al., 1980} & Solubility in $\mathrm{NaCl}$ & $\sim 7$ & 12 & 6.14 \\
\hline & in $\mathrm{KNO}_{3}$ & $\sim 7$ & 12 & 3.76 \\
\hline & in $\mathrm{KCl}$ & $\sim 7$ & 12 & 4.81 \\
\hline Marshall, 1980 & Solubility in $\mathrm{NaNO}_{3}$ & $\sim 7$ & 9 & 6.12 \\
\hline Svensson et al., 1986 & $\mathrm{NMR}, \mathrm{pH}$ in $\mathrm{NaOH}$ & $11.3-14$ & 18 & 20 \\
\hline McCormick et al., 1987 & $\mathrm{NMR}, \mathrm{pH}$ in $\mathrm{NaOH}$ & $11.3-13.4$ & 5 & 4.2 \\
\hline
\end{tabular}

\section{A.3 POLYMERIZATION AND IONIZATION}

The most common approach to modeling silicate species in high caustic solutions is to select several species as representative samples and to estimate empirical formation constants. One study assumed only the monomer and the dimer, but it allowed all possible ionizations of each (Sefč́i et al., 1997). Most other modelers (Svensson et al., 1986; Caullet et al., 1989; Grenthe et al., 1992; Eikenberg et al., 1990; Sjöberg et al., 1985) have included higher polymeric species as well. This study has also included the higher polymers since it is more comprehensive. In addition, a single representative polymer for each connectivity group was selected. With the exception of the linear trimer and the linear tetramer, the polymers in Table A.1 were used.

Formation constants are defined for the formation of polymeric species from silicic acid:

$$
j(0,1) \leftrightarrow i \mathrm{H}^{+}+(i, j) \quad Q_{i j}=\frac{\left[\mathrm{H}^{+}\right]^{i}[(i, j)]}{[(0,1)]^{j}},
$$

where square brackets denote concentration in molality. It is understood that water itself may be either a reactant or product. An alternative formulation is based on individual silicon atoms.

$$
(0,1) \leftrightarrow \frac{i}{j} \mathrm{H}^{+}+\frac{1}{j}(i, j) \quad \tilde{Q}_{i j}=\frac{\left[\mathrm{H}^{+}\right]^{i / j}[(i, j)]^{1 / j}}{[(0,1)]}
$$


Table A.3. Calculated parameters at $25^{\circ} \mathrm{C}$

\begin{tabular}{cccccc}
\hline $\mathrm{Species}$ & $\beta^{(0)}$ & $\beta^{(1)}$ & $C$ & $\Delta \mathrm{G}_{298}^{\circ} / \mathrm{RT}$ & $\lambda$ \\
\hline $\mathrm{Na}-\mathrm{OH}$ & 0.0864 & 0.2530 & 0.0021 & & \\
$\mathrm{Na}-\mathrm{Cl}$ & 0.0759 & 0.2765 & -0.00065 & & \\
$\mathrm{~K}-\mathrm{Cl}$ & 0.0479 & 0.2203 & 0.0037 & & \\
$\mathrm{~K}-\mathrm{NO}_{3}$ & 0.08061 & 0.07641 & 0.0250 & & \\
$\mathrm{Na}-\mathrm{NO}_{3}$ & 0.00216 & 0.2422 & 0.00007 & & \\
$\mathrm{Na}-(0,1)^{a}$ & & & & -528.074 & \\
$\mathrm{Na}-(1,1)$ & 0.0734 & 2.7216 & -0.0108 & -505.074 & \\
$\mathrm{Na}-(2,1)$ & 0.2182 & 9.9072 & -0.0074 & -479.236 & \\
$\mathrm{Na}-(2,2)$ & -0.3282 & 2.7191 & 0.0165 & -457.310 & \\
$\mathrm{Na}-(4,2)$ & 0.1927 & 7.6205 & -0.0063 & -429.861 & \\
$\mathrm{Na}-(6,3)$ & -0.0441 & -0.4372 & 0.0100 & -374.458 & \\
$\mathrm{Na}-(4,4)$ & -0.1954 & 1.4228 & 0.0105 & -410.720 & \\
$\mathrm{Na}-(6,6)$ & -0.2761 & 4.3188 & 0.0149 & -363.303 & \\
$\mathrm{Na}-(4,8)$ & -0.1265 & -0.5069 & 0.0087 & -376.510 & \\
$\mathrm{Na}-(8,8)$ & -0.2457 & 4.5521 & 0.0131 & -363.920 & \\
$\mathrm{SiO}{ }_{2}$ & & & & -342.911 & \\
$\mathrm{Na}-\mathrm{Si}(\mathrm{OH})_{4}{ }^{b}$ & & & & & 0.05714 \\
$\mathrm{~K}-\mathrm{Si}(\mathrm{OH})_{4}$ & & & & & \\
$\mathrm{NO}{ }_{3}-\mathrm{Si}(\mathrm{OH})_{4}$ & & & & & \\
$\mathrm{Cl}-\mathrm{Si}(\mathrm{OH})_{4}$ & & & & & \\
\hline
\end{tabular}

${ }^{a}$ Grenthe et al., 1992.

${ }^{b}$ By definition.

The use of Eq. (6b) allows calculation of ionic strength based on the charge per silicon atom rather than on the total charge of each polymeric molecule. This is somewhat more realistic since a charge of -1 per silicon atom in the cubic octamer should not contribute to the ionic strength as if it were a single ion of charge -8 . It could easily be argued that the charge contribution should count for more than just -1 as well. An additional problem arises if the charge per silicon atom is not an integer. In this case, ionic strength can still be calculated using a charge of $-1 / 2$. Thus, both Eqs. (6a) and (6b) 
encounter difficulties because the concept of ionic strength was not developed with polymeric ions in mind. In practice, Eq. (6b) produces a better fit to data, and all of the results in this study are based on Eq. (6b).

Data obtained from NMR analysis and $\mathrm{pH}$ measurements are especially useful in establishing silicate aqueous species. Initially, the exact set of silicate species (Sjöberg et al., 1985) was selected for this study since the results comprise more than half of the data used in this study. The optimal parameter fits were obtained for the same formation constants. However, this analysis is based on molal rather than molar concentration. In addition, this evaluation considered the large polymer to be neutral since each of the 32 silicon atoms is connected to four other silicon-oxygen groups. Therefore, no hydroxyl groups are available to ionize.

Formation constants are fitted to the linear form:

$$
\log _{10} Q_{i j}=\log _{10} K_{i j}+\alpha_{i j} m_{\mathrm{Na}^{+}}+\mathrm{DH}
$$

where DH is the Debye-Hückel term [Sjöberg et al., 1985]:

$$
\mathrm{DH}=\mathrm{A} \sqrt{\mathrm{I}}(1+1.5 \sqrt{\mathrm{I}})
$$

The $K_{i j}$ are equilibrium constants and $\alpha_{i j}$ are the linear-term coefficients corresponding to species $(i, j)$. The optimal formation constants are shown in Table A.4.

Table A.4. Optimal formation constants

\begin{tabular}{ccc}
\hline Species & $\mathrm{K}_{\mathrm{ij}}$ & $\alpha_{\mathrm{ij}}$ \\
\hline$(1,2)$ & -9.425 & -0.1374 \\
$(2,2)$ & -16.999 & -0.2694 \\
$(4,2)$ & -43.557 & -0.378 \\
$(3,3)$ & -25.559 & -0.4338 \\
$(6,3)$ & -65.007 & -0.5529 \\
$(2,4)$ & -10.187 & -0.4587 \\
$(4,4)$ & -32.842 & -0.5836 \\
$(8,4)$ & -86.595 & -0.724 \\
$(3,6)$ & -14.209 & -1.1056 \\
$(6,6)$ & -49.65 & -0.8827 \\
$(4,8)$ & -18.967 & -1.005 \\
$(8,8)$ & -65.428 & -1.1829 \\
$(0,32)$ & -105.088 & -3.0864 \\
\hline
\end{tabular}


This set of species proved inadequate below the polymeric range since the large polymer term $(0,32)$ superceded amorphous silica even at neutral $\mathrm{pH}$. One possible correction (Svensson et al., $1986)$ was to consider the large polymer as a charged particle $(16,32)$. However, the fit was inferior, and the problem at neutral $\mathrm{pH}$ persisted. Finally, a single species was selected to represent both amorphous silica as well as a generic nonionic polymer of unspecified size. The results from this set of species produced good fits of data, although they did not distinguish between amorphous silica and large polymeric particles. It should be noted that NMR spectroscopy encounters the same difficulty.

\section{A.4 PITZER'S MODEL}

It is desirable to formulate a model of silicate behavior which can be incorporated into a more general electrolyte model. The model used in this work includes Pitzer's ion-interaction treatment for activity coefficients and a routine for calculation of chemical equilibria using Gibbs energy minimization. In addition, the parameter estimation process uses a nonlinear least-squares procedure to determine optimal values for unknown parameters.

The important parameters are the Gibbs energies of formation, $\Delta G_{298}^{\circ}$, for each species and the interaction coefficients, $\beta^{(0)}, \beta^{(1)}$, and $C$, associated with Pitzer's method. Values for the species other than the silicates were previously determined, while the values for the silicate species were calculated from fits of the NMR and pH data. All of these results, which are listed in Table A.3, were determined at $25^{\circ} \mathrm{C}$ since very little information is available at other temperatures. The considerable correlation between many of the parameters suggests that none should be used independently of the others. Therefore, all parameters together constitute a single model which adequately describes the experimental results.

During the parameter estimation process, numerous combinations of species were used. The resulting set of species is based on the fewest number which could adequately describe the experimental results. The initial estimates for the Gibbs energies were obtained from the equilibrium constants in Eq. (6b) or from previous optimization runs. The initial estimates for Pitzer parameters were zero, which corresponds to ideal solution behavior.

\section{A.5 RESULTS AND DISCUSSION}

Using the optimal results in Table A.3, silicate solution equilibria were recalculated and are compared with the experimental results in Figs. A.1-A.12. For Figs. A.1-A.8, a perfect match between the experimental result and the predicted value would lie on the diagonal line. From these figures, the calculations match experimental values fairly well for $\mathrm{pH}$ and all NMR results with the exception of $\mathrm{Q}^{4}$. It is important to remember that $\mathrm{Q}^{4}$ represents both large polymers and amorphous silica. In addition, the potential of experimental error in the NMR results on the large polymers and amorphous silica increased due to the large band of low amplitude and possible interference from quartz sample tubes. 


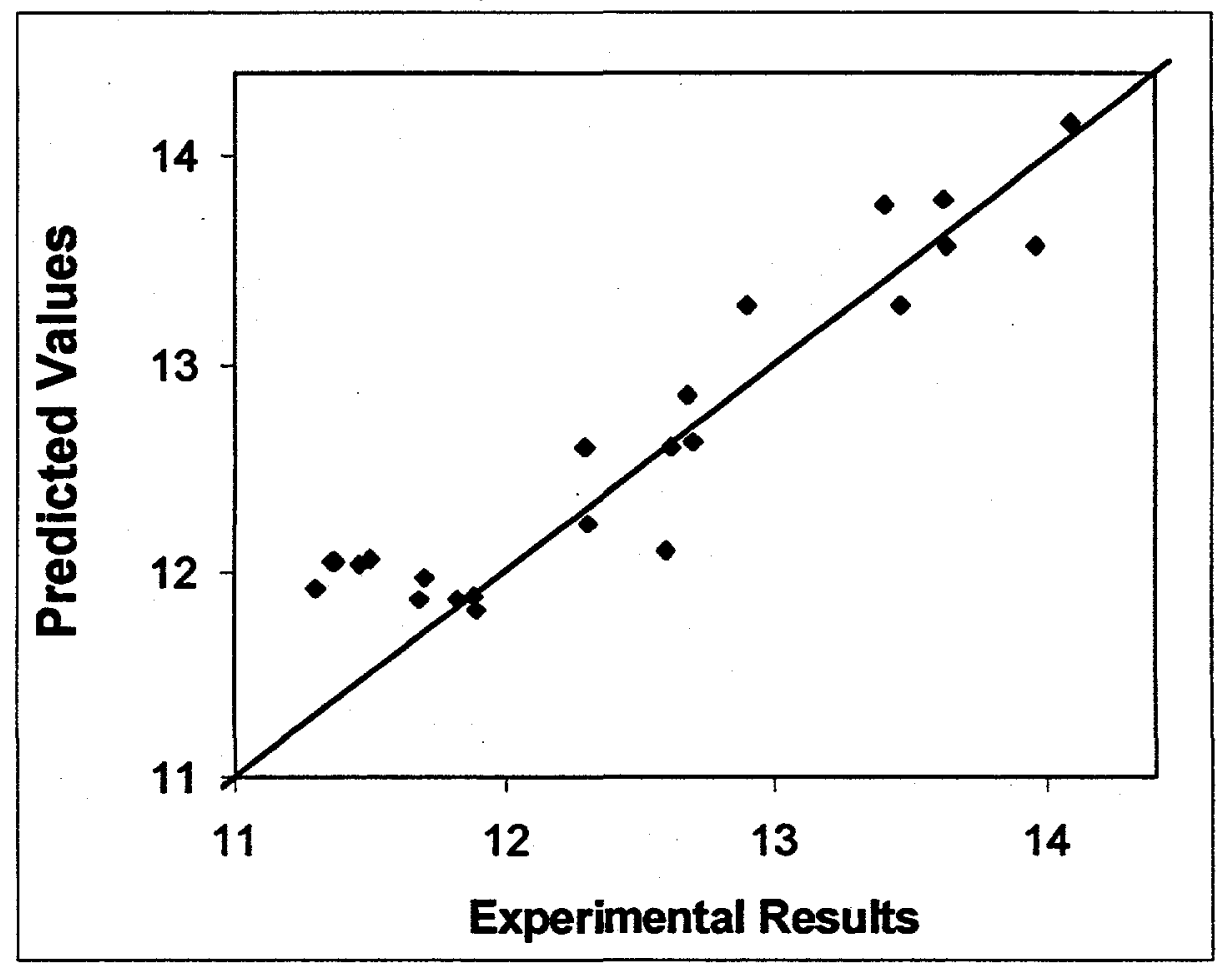

Fig. A.1. pH of NMR solutions.

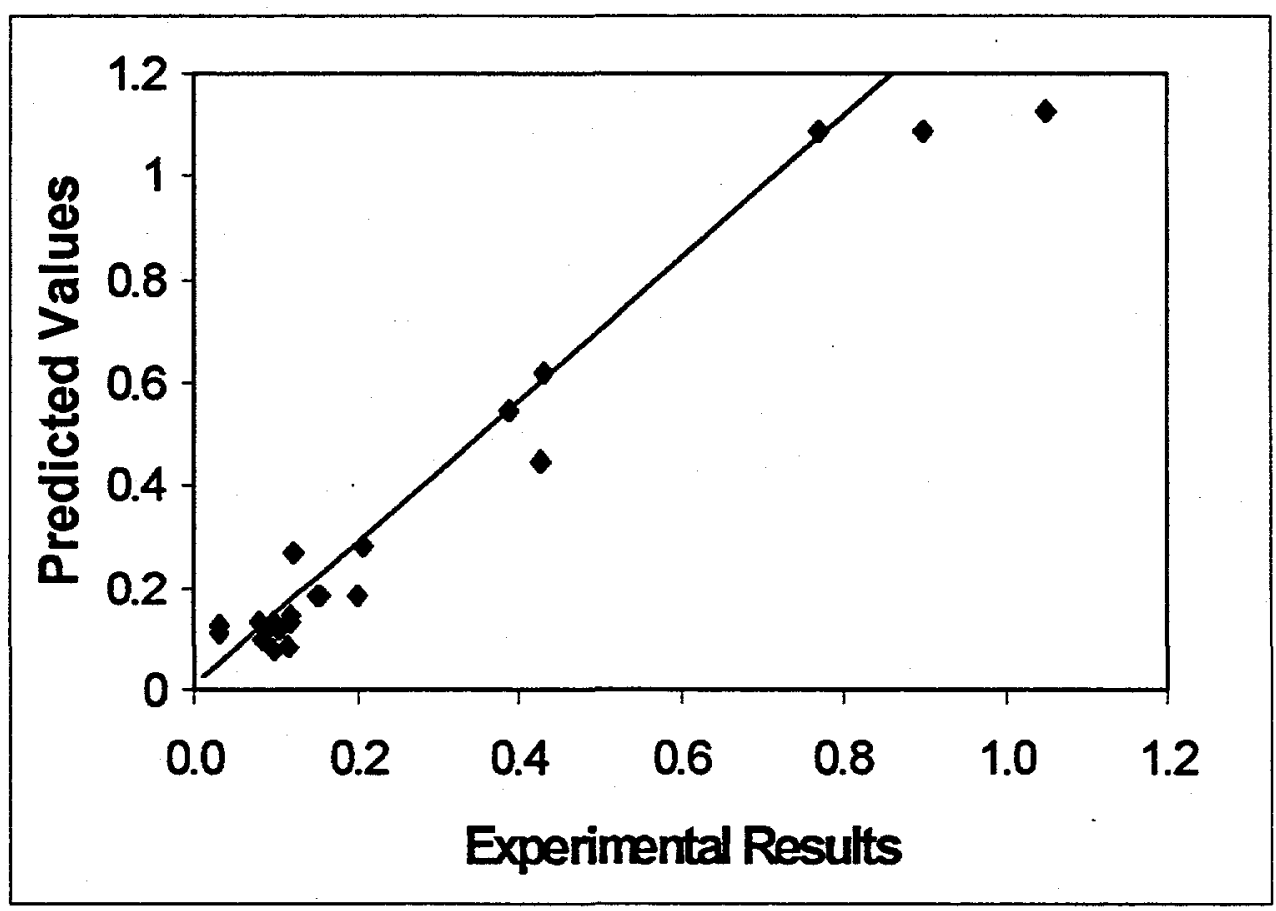

Fig. A.2. $Q^{\circ}$ connectivity group. 


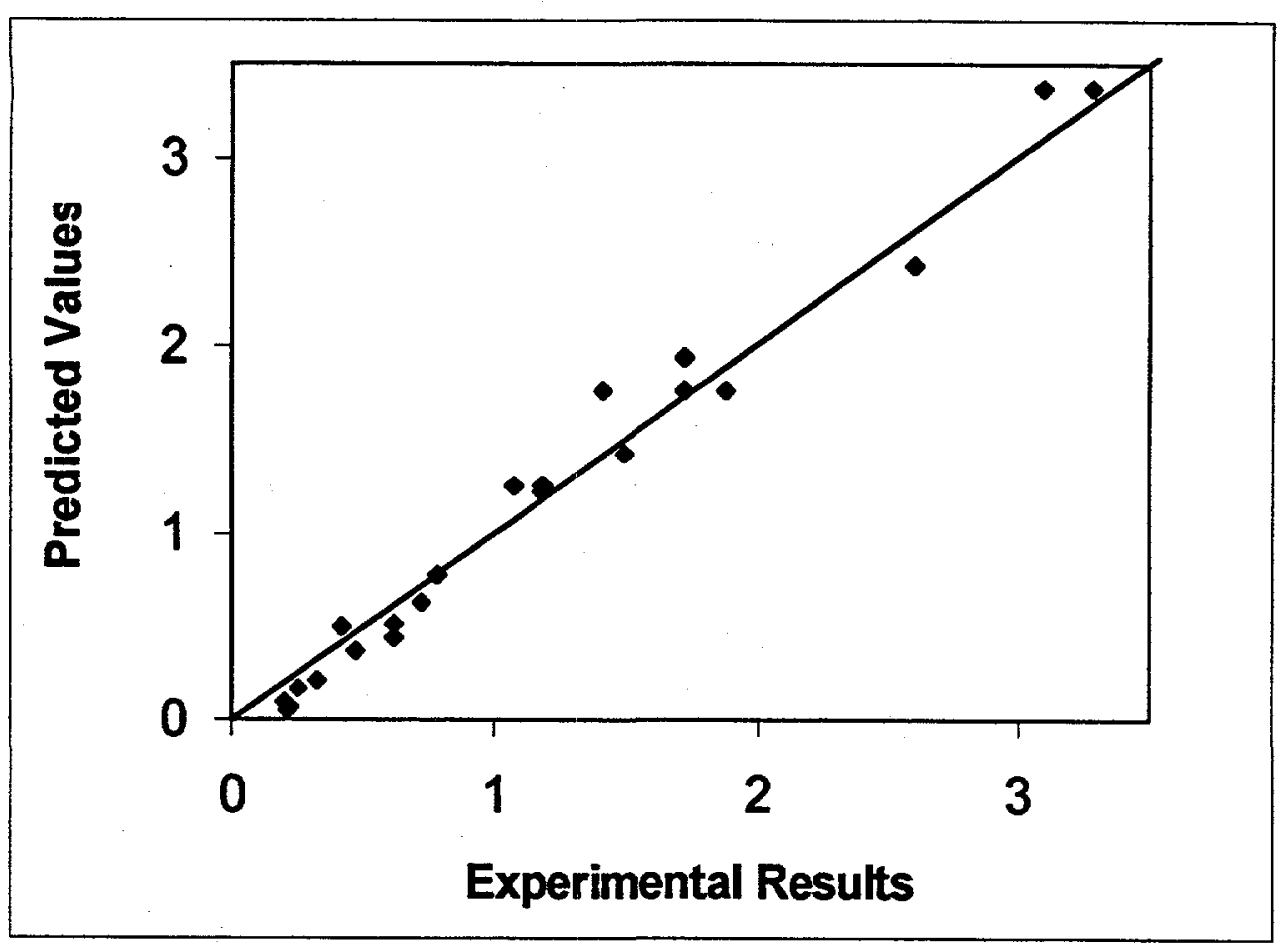

Fig. A.3. $Q^{1}$ connectivity group.

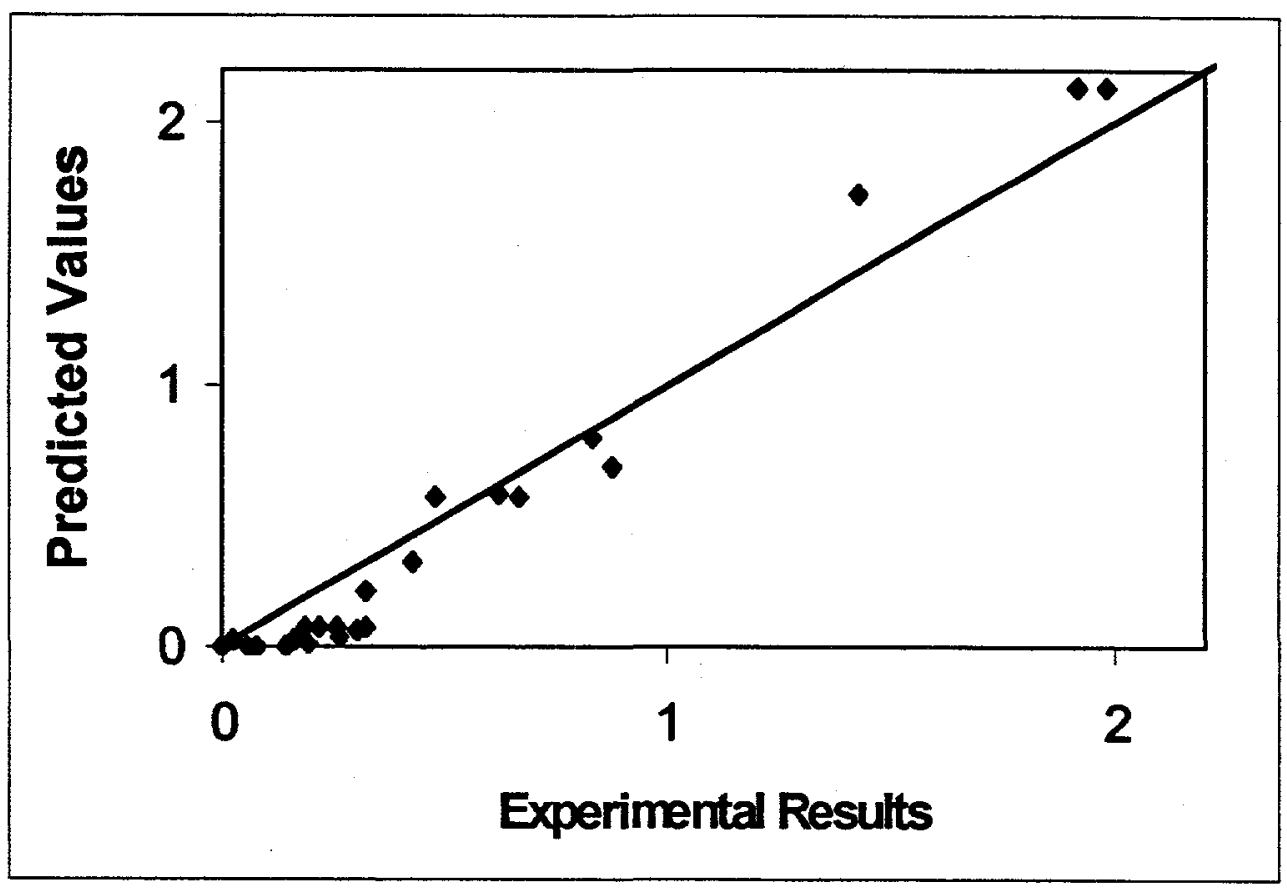

Fig. A.4. $Q_{\Delta}{ }^{2}$ connectivity group. 


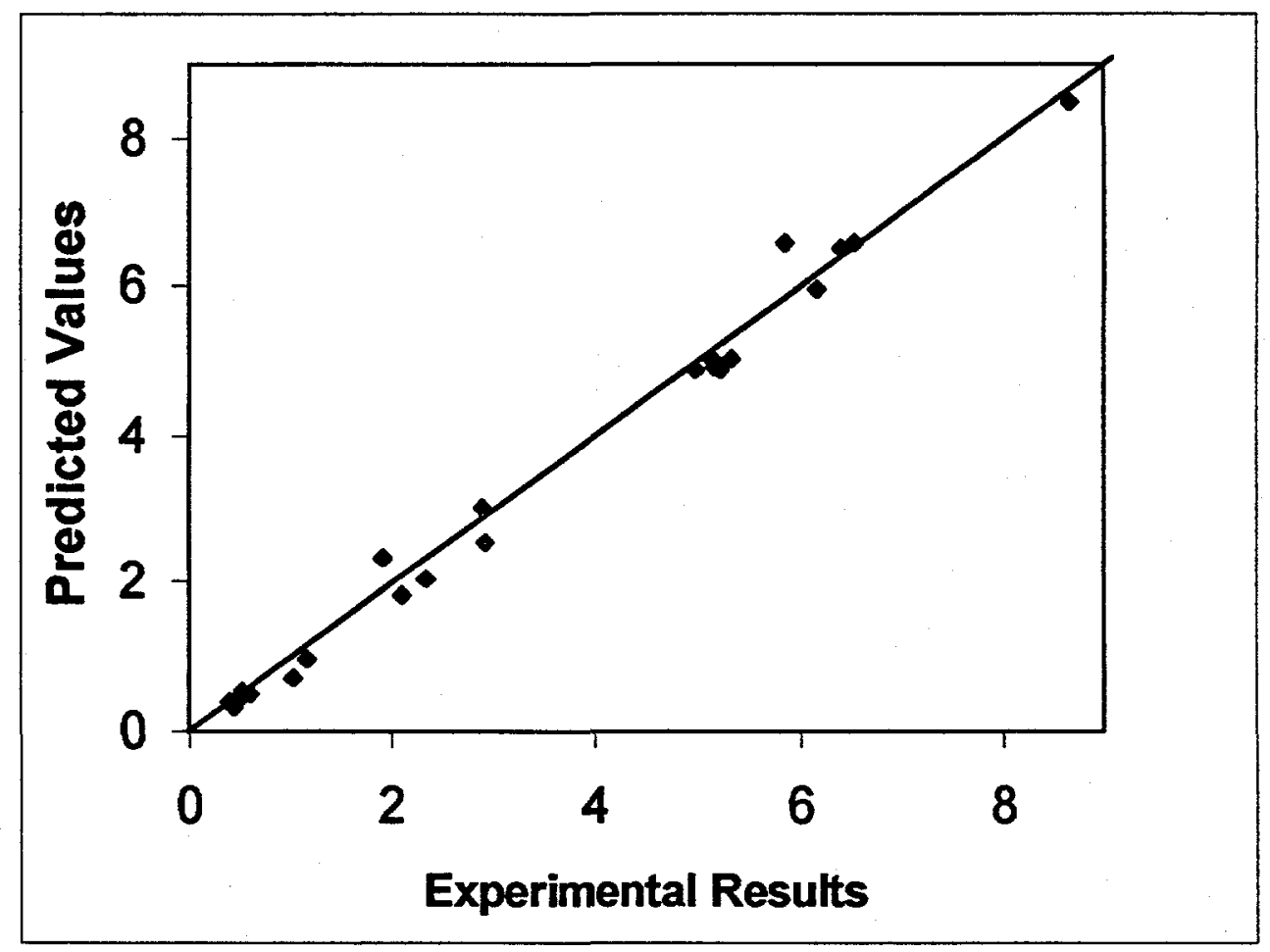

Fig. A.5. $Q^{2}$ connectivity group.

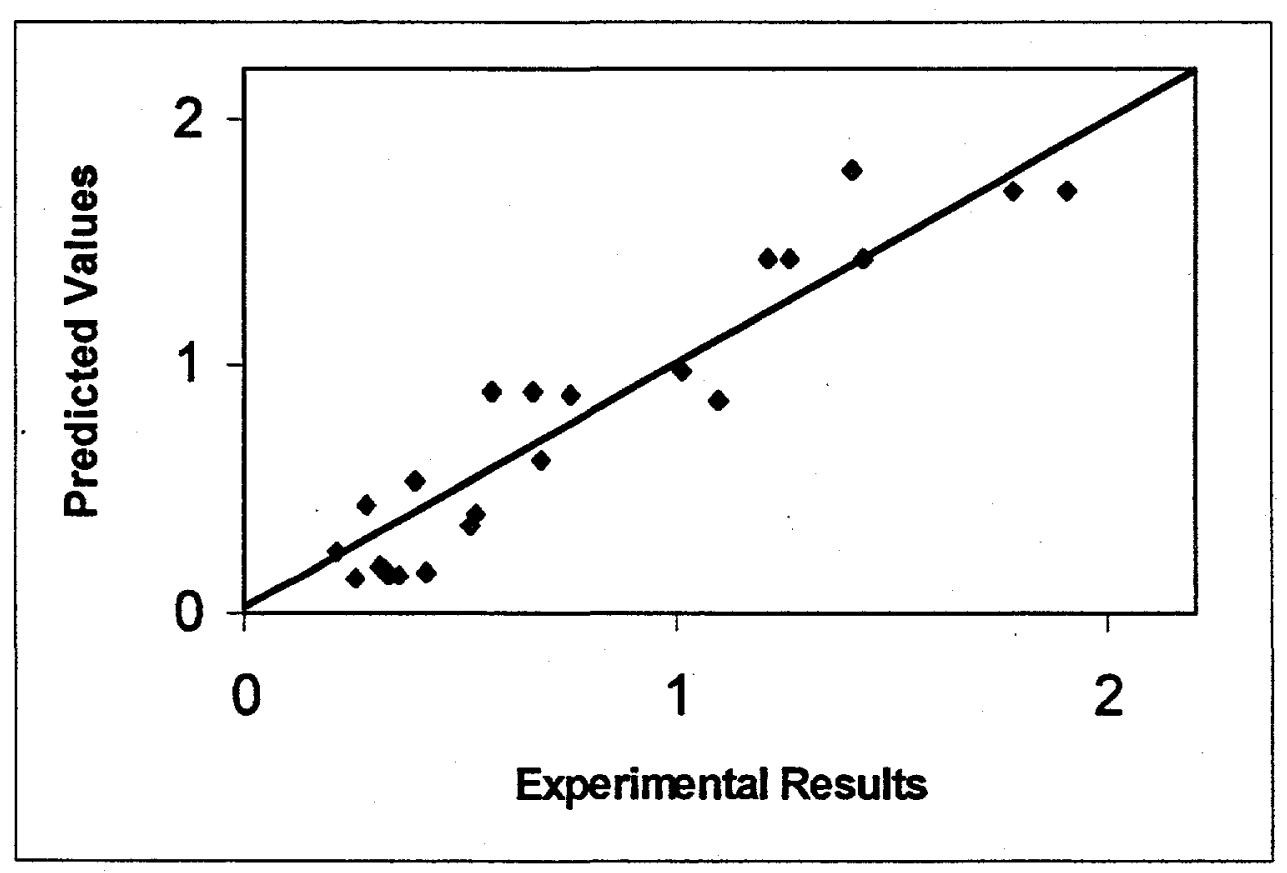

Fig. A.6. $\mathrm{Q}_{\Delta}^{3}$ connectivity group. 


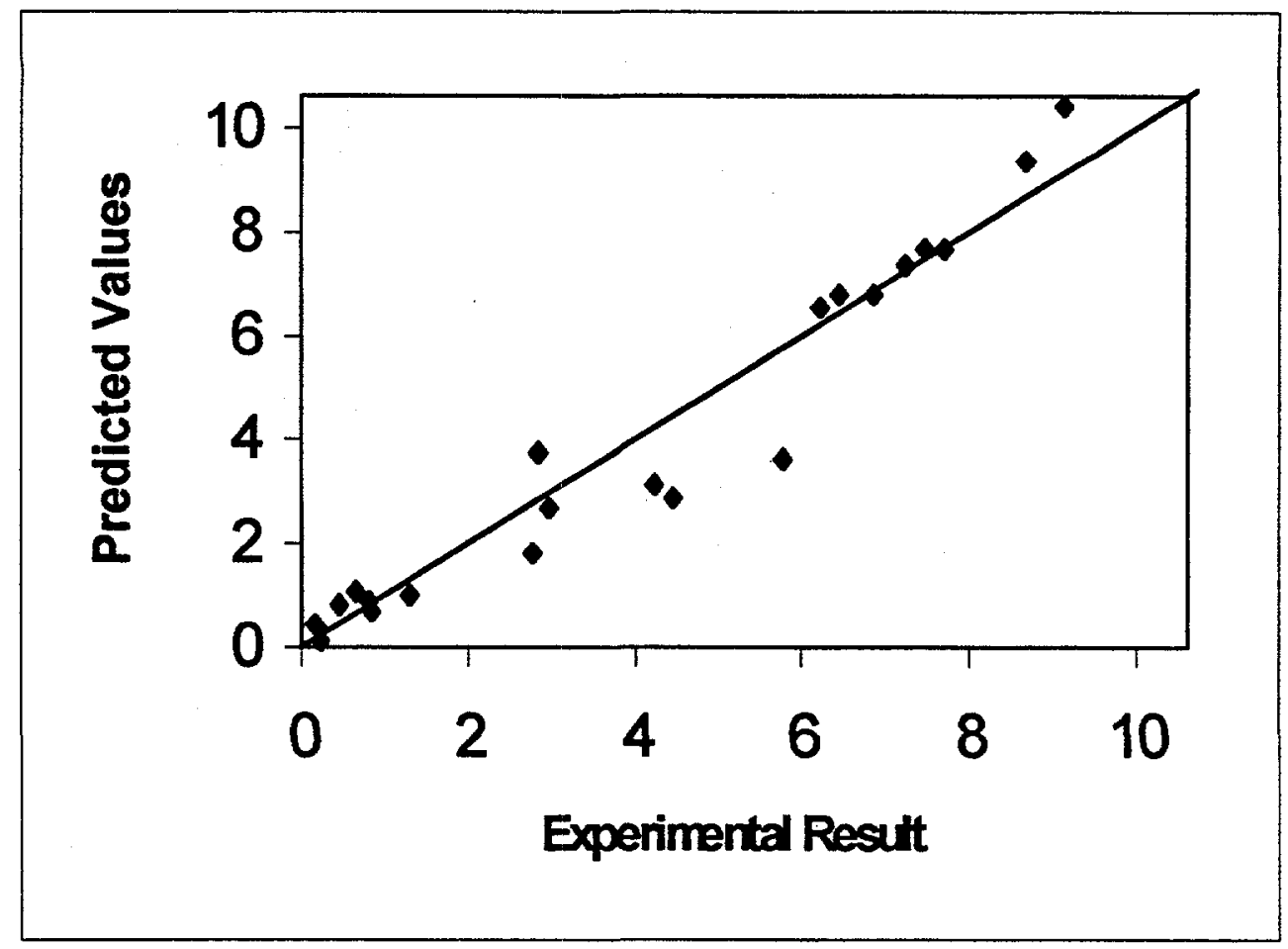

Fig. A.7. $Q^{3}$ connectivity group.

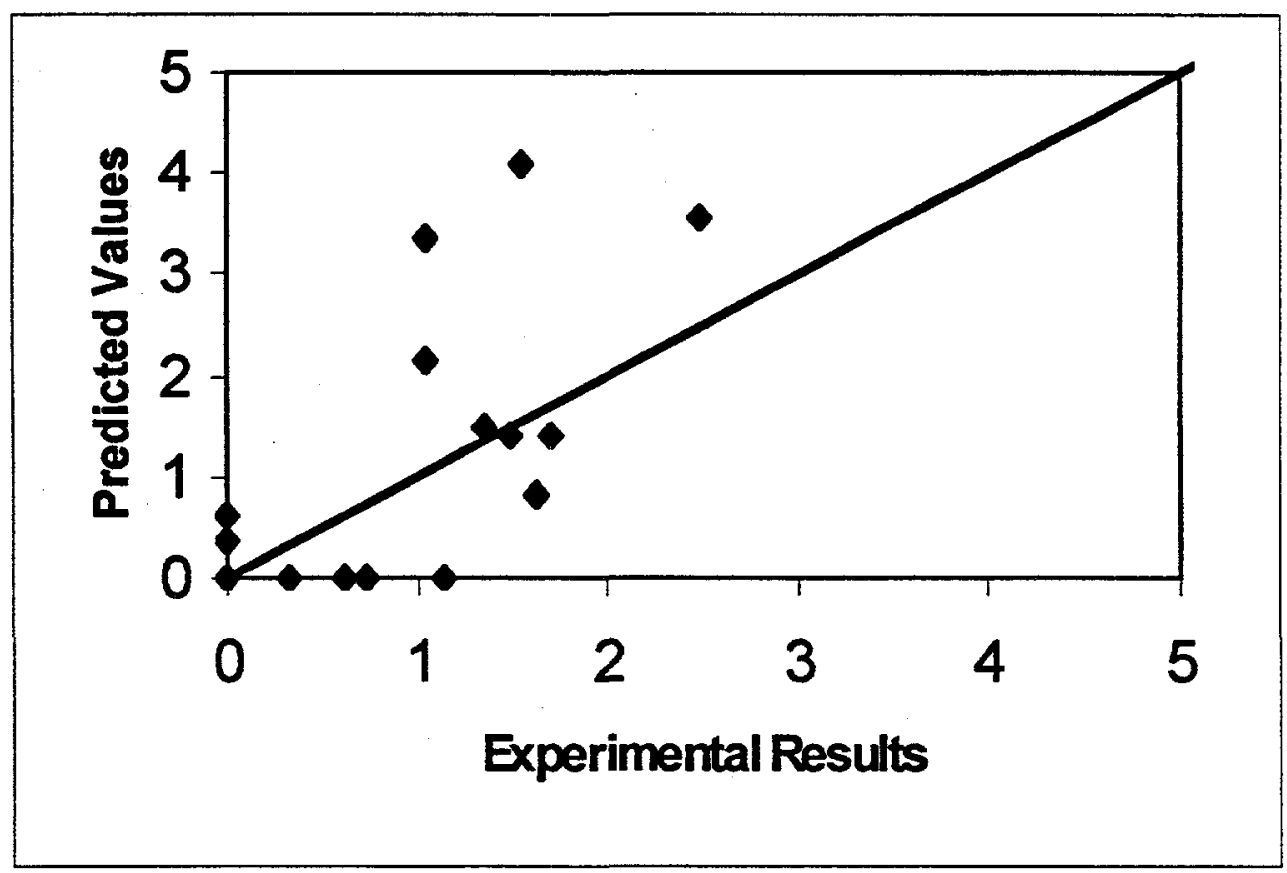

Fig. A.8. $Q^{4}$ connectivity group. 


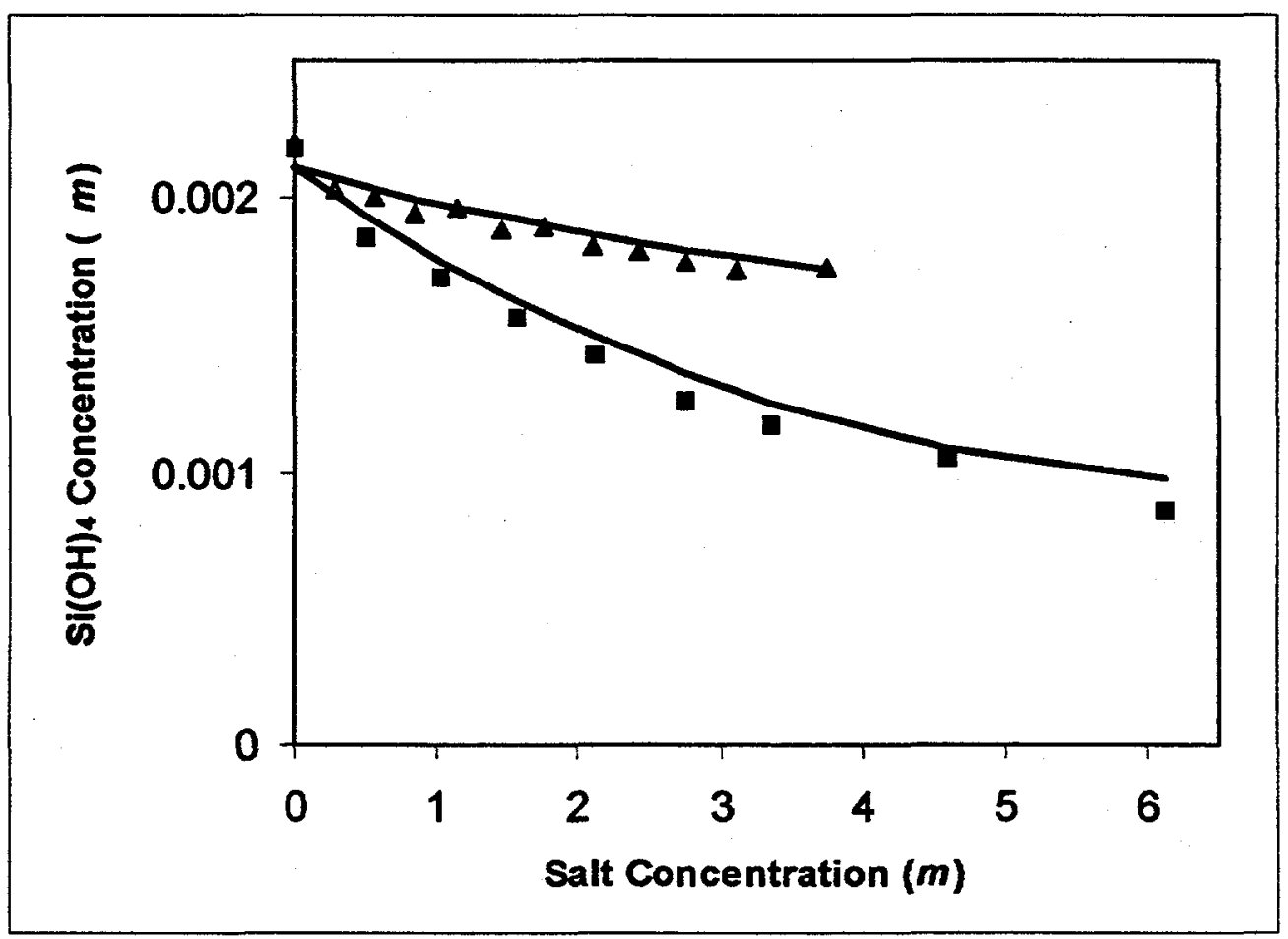

Fig. A.9. Solubilities in neutral salt solutions: $\square-\mathrm{NaNO}_{3}$ and $\mathbf{A}-\mathrm{KNO}_{3}$.

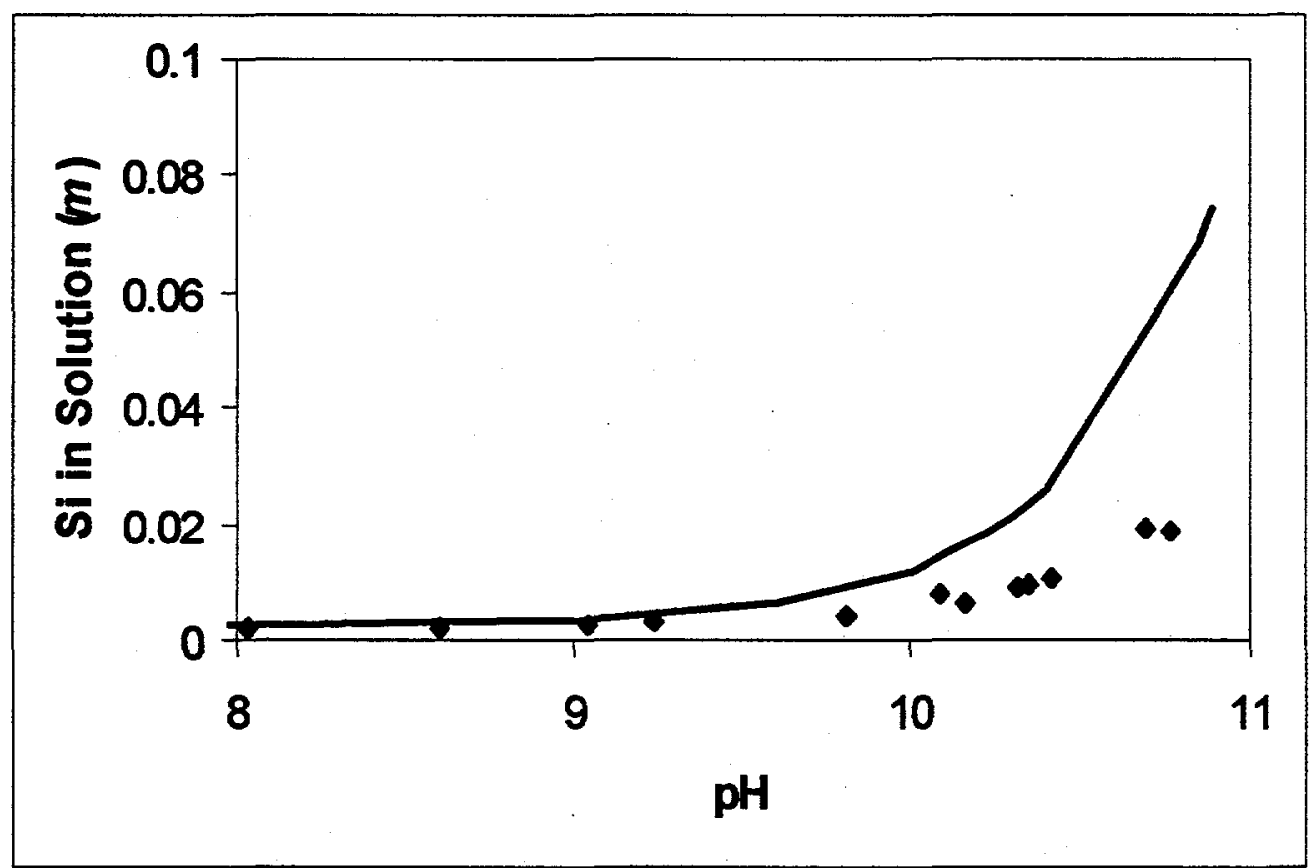

Fig. A.10. Silicate solubility in sodium hydroxide solutions. 


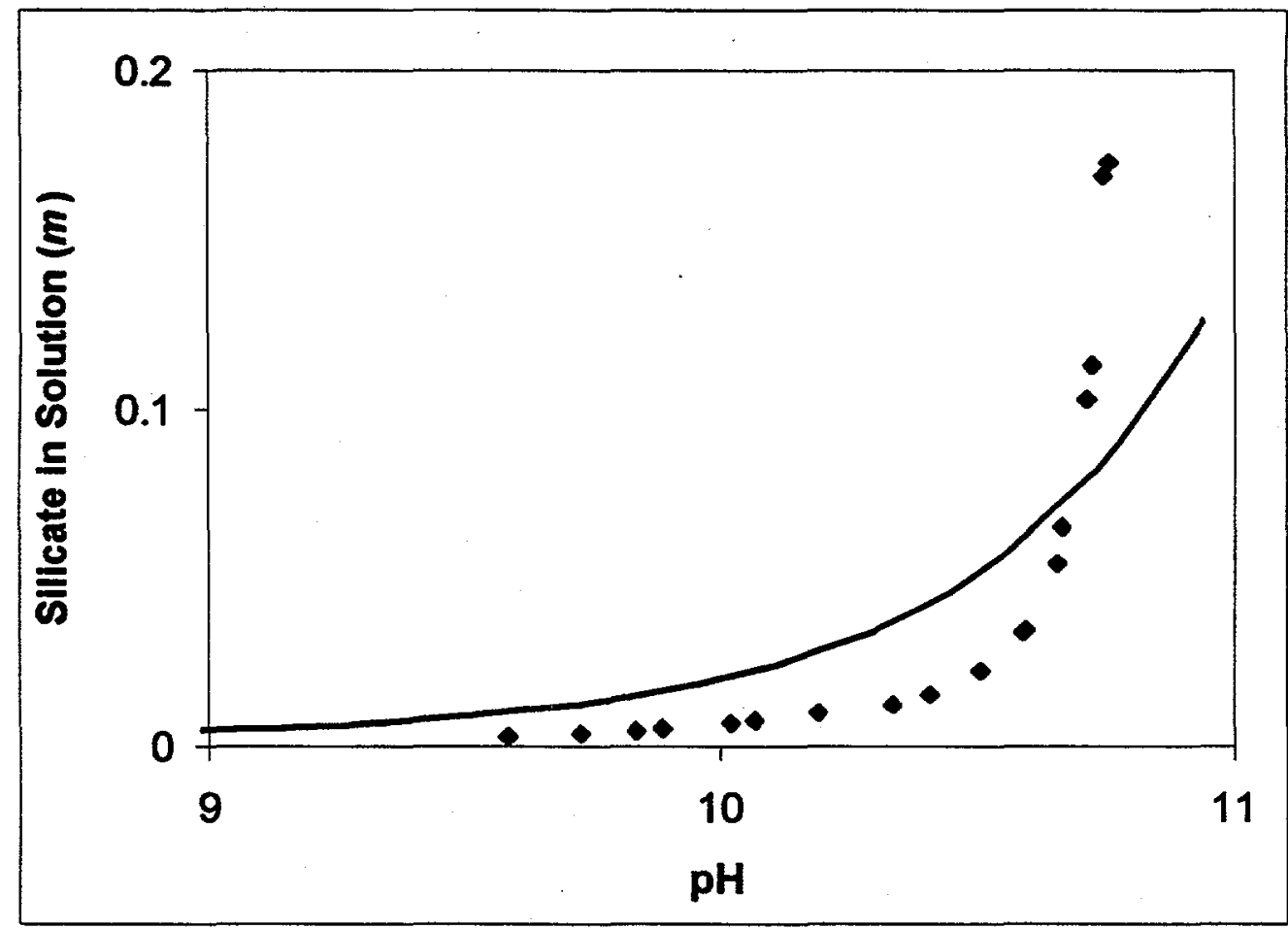

Fig. A.11. Silicate solubility in sodium hydroxide and $1 M$ sodium chloride solutions.

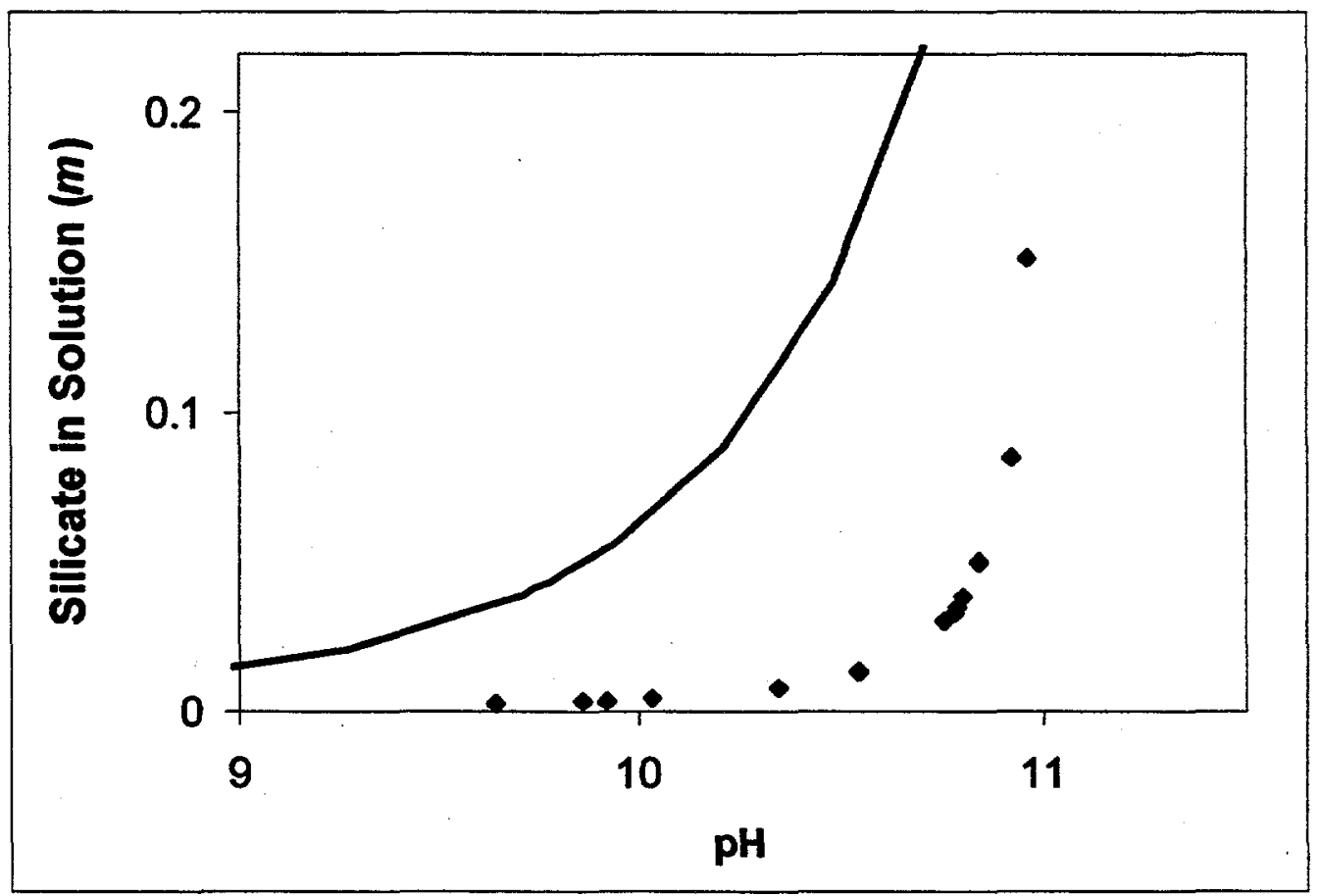

Fig. A.12. Silicate solubility in sodium hydroxide and $3 M$ sodium chloride solutions. 
Figures A.9-A.12 depict various solubility results. Figure A.9 shows solubility of amorphous silica in two salt solutions at near neutral $\mathrm{pH}$. Similar results are also true for sodium chloride and potassium chloride salts. The close match between the calculations and the experimental results indicates that the neutral-salt parameters $\lambda_{i j}$ are reliable. Figures A.10-A.12 show amorphous silica solubility in water and sodium chloride solutions as sodium hydroxide concentration is increased. The predicted values match the experimental results for $\mathrm{pH}$ values of 9.5 and less, but a marked deviation begins at higher $\mathrm{pH}$. Part of the problem is due to the combination of amorphous silica and large neutral polymer as a single species. Work is ongoing to try to improve the model to better fit these experimental results.

\section{A.6 REFERENCES}

G. B. Alexander, W. M. Heston, and R. K. Iler. 1954. "The Solubility of Amphorous Silica in Water," J. Phys. Chem., 58, 453.

P. Caullet and J. L. Guth. 1989. Zeolite Synthesis, American Chemical Society, Washington, D.C.

J. Eikenberg. 1990. On the Problem of Silica Solubility at High pH, PSI-Bericht Nr. 74, Paul Scherrer Institut.

I. Grenthe, J. Fuger, R. J.M. Konings, R. M. Lemire, A. B. Muller, C. Nguyen-Trung, and H. Wanner. 1992. Chemical Thermodynamics of Uranium, North-Holland, Amsterdam, Netherlands.

W. L. Marshall. 1980. "Amphorous Silica Solubilities - I. Behavior in Aqueous Sodium Nitrate Solutions; 25-300 ${ }^{\circ}$, 0-6 Molal," Geochim. Cosmochim. Acta, 44, 907.

W. L. Marshall and J. M. Warakomski. 1980. "Amphorous Silica Solubilities - II. Effect of Aqueous Salt Solutions at $25^{\circ} \mathrm{C}, "$ Geochim. Cosmochim. Acta, 44, 915.

A. V. McCormick, A. T. Bell, and C. J. Radke. 1987. "Quantitative Demonstration of Siliceous Species in Sodium Silicate Solutions by Silicon-29 NMR Spectroscopy," ZEOLITES, 7; 183.

J. SefčíK and A. V. McCormick. 1997. "Thermochemistry of Aqueous Silicate Solution Precursors to Ceramics," AIChE Journal, 43(11A), 2773.

S. Sjöberg, L.-O. Öhman, and N. Ingri. 1985. "Equilibrium and Structural Studies of Silicon (IV) and Aluminum (III) in Aqueous Solution. 11. Polysilicate Formation in Alkaline Aqueous Solution. A Combined Potentiometric and ${ }^{29}$ Si NMR Study," Acta Chem. Scand. A, 39, 93.

I. L. Svensson, S. Sjöberg, and L.-O. Öhman. 1986. "Polysilicate Equilibria in Concentrated Sodium Silicate Solutions," J. Chem. Soc. Far. Trans. 1, 82, 3635.

D. P. Zarubin and N. V. Menkina. 1990. "The Solubility of Amphorous Silica in an Alkaline Aqueous Media at a Constant Ionic Strength," Russ. J. Inorg. Chem., 35(1), 16. 
ORNL/TM-1999/263

\section{INTERNAL DISTRIBUTION}

\author{
1. C. W. Chase \\ 2. J. L. Collins \\ 3. A. G. Croff \\ 4. T. A. Dillow \\ 5-14. R. D. Hunt \\ 15. R. T. Jubin \\ 16. C. P. McGinnis
}
17. L. E. McNeese
18. S. M. Robinson
19. C. F. Weber
20. T. D. Welch
21. Central Research Library
22. ORNL Laboratory Records-RC
23-24. ORNL Laboratory Records-OSTI

\section{EXTERNAL DISTRIBUTION}

25. Ed Beahm, 106 Cooper Circle, Oak Ridge, TN 37830

26. Jimmy Bell, 137 Bowspirit Lane, Kingston, TN 37763

27. Alan Carlson, Numatec Hanford Corporation, P.O. Box 1300, MS R3-73, Richland, WA 99352

28. Penny Colton, Pacific Northwest National Laboratory, Battelle Boulevard, P.O. Box 999, MS K8-93, Richland WA 99352

29. Joe Cruz, U.S. Department of Energy, Richland Operations Office, P.O. Box 550, MS H6-60, Richland, WA 99352

30. Sam Fink, Westinghouse Savannah River Company, Savannah River Technology Center, Building 773-A, Room B-112, Aiken, SC 29808

31. Thomas Guttman, U.S. Department of Energy, Savannah River Operations Office, P.O. Box A, Aiken, SC 29802

32. Dan Herting, Numatec Hanford Corporation, P.O. Box 1300, MS T6-07, Richland, WA 99352

33. David Hobbs, Westinghouse Savannah River Company, Savannah River Technology Center, Building 773-A, Room B-117, Aiken, SC 29808

34. Jim Honeyman, Lockheed Martin Hanford Corporation, P.O. Box 1500, MS G3-21, Richland, WA 99352

35. James Jewett, Numatec Hanford Corporation, P.O. Box 1300, MS R3-73, Richland, WA 99352

36. Randy Kirkbride, Numatec Hanford Corporation, P.O. Box 1300, MS H5-27, Richland, WA 99352

37. Louis Kovach, Hanford, P.O. Box 1970, K6-51, Richland WA 99352

38. Jeff Lindner, DIAL, 205 Research Blvd., Starkville, MS 39759

39. Frank Mao, Hemispheric Center for Environmental Technology, Florida International University, 10555 W. Flagler Street, Suite 2100, Miami, FL 33174 
40. Jerome Morin, Westinghouse Savannah River Company, Savannah River Technology Center, Building 703-H, Room 119, Aiken, SC 29808

41. Jacquie Noble-Dial, U.S. Department of Energy, Oak Ridge Operations Office, P.O. Box 2001, Oak Ridge, TN 37830-8620

42. Wally Schultz, W2S Company, Inc., 5314 Arbustos Court, NE, Albuquerque, NM 87111

43. John Swanson, 1318 Cottonwood Drive, Richland, WA 99352

44. Major Thompson, Westinghouse Savannah River Company, Savannah River Technology Center, Building 773-A, Room C-140, Aiken, SC 29808

45. Rebecca Toghiani, Department of Chemical Engineering, Mississippi State University, P.O. Box 9595, Mississippi State, MS 39762

46. George Vandegrift, Argonne National Laboratory, 9700 South Cass Avenue, Building 205, Argonne, IL 60439

47. Ray Wymer, 188-A Outer Drive, Oak Ridge, TN 37830

48-55. Tanks Focus Area Technical Team, c/o B. J. Williams, Pacific Northwest National Laboratory, Battelle Boulevard, P.O. Box 999, MSIN K9-69, Richland WA 99352

56. Tanks Focus Area Field Lead, c/o T. P. Pietrok, U.S. Department of Energy, Richland Operations Office, P.O. Box 550, MS K8-50, Richland, WA 99352 